\title{
Therapeutic Options for Visceral Leishmaniasis
}

\author{
Begoña Monge-Maillo $\cdot$ Rogelio López-Vélez
}

Published online: 30 October 2013

(C) The Author(s) 2013. This article is published with open access at Springerlink.com

\begin{abstract}
Visceral leishmaniasis (VL), also known as Kala-Azar, is a disseminated protozoal infection caused principally by Leishmania donovani and Leishmania infantum (known as Leishmania chagasi in South America). The therapeutic options for VL are diverse and depend on different factors, such as the geographical area of the infection, development of resistance to habitual treatments, HIV co-infection, malnourishment and other concomitant infections. This article provides an exhaustive review of the literature regarding studies published on the treatment of $\mathrm{VL}$, and gives therapeutic recommendations stratified according to their level of evidence, the species of Leishmania implicated and the geographical location of the infection.
\end{abstract}

\section{Introduction}

Visceral leishmaniasis (VL), also known as Kala-Azar, is a disseminated protozoal infection caused principally by Leishmania donovani and Leishmania infantum (synonym Leishmania chagasi in South America). Occasionally, Leishmania tropica in the Middle East and Leishmania amazonensis in South America can produce VL [1].

Leishmania spp. are transmitted through the bite of female haematophageous sand flies from the genus Phlebotomus in the Old World and Lutzomyia in the New World. Depending on the transmission characteristics, two

B. Monge-Maillo · R. López-Vélez $(\bowtie)$

Tropical Medicine and Clinical Parasitology, Infectious Diseases Department, Ramón y Cajal Hospital, Instituto Ramón y Cajal de Investigación Sanitaria (IRYCIS), Carretera de Colmenar Km 9,1, 28034 Madrid, Spain

e-mail: rogelio.lopezvelez@salud.madrid.org types of VL have been described. The zoonotic form, caused mainly by $L$. infantum, with dogs as the main reservoir, occurs in the Mediterranean Basin, China, the Middle East and South America. The anthroponotic form, with human-to-human transmission without an animal reservoir, caused mainly by $L$. donovani, is prevalent in East Africa, Bangladesh, India and Nepal.

The worldwide prevalence of $\mathrm{VL}$ is estimated to be 12 million cases, with approximately 0.2 to 0.4 million new VL cases each year. More than $90 \%$ of global VL cases occur in just six countries: India, Bangladesh, Sudan, South Sudan, Brazil and Ethiopia [2]. Co-infection with HIV and Leishmania has been reported in more than 35 countries. Initially, most of the cases were from southwestern Europe, but the number of cases is increasing in Sub-Saharan Africa (particularly in Ethiopia), in Brazil and in South Asia. Co-infection in India still seems not to be a major problem and occurs in $<2 \%$ of VL patients [3].

Since the late 1940s, the traditional treatment for VL has been the use of pentavalent antimonials. However, in the 1980s, conventional amphotericin B deoxycholate was introduced, followed by lipid formulations of amphotericin B-mainly liposomal amphotericin B-with high efficacy and low toxicity. Paromomycin was then incorporated as a cheap and effective parenteral drug, which can be easily administered as an intramuscular (IM) injection. Later, miltefosine was developed as an oral drug option for VL. Nonetheless, clear differences in the clinical efficacy of these drugs have been observed and are based on several factors, which must be taken into consideration in treatment decisions, such as the geographical area of the infection [4], development of resistance (a striking fact in the case of pentavalent antimonials in India over the last couple of decades [5, 6]), HIV-Leishmania co-infection, malnourishment and other concomitant infections [6]. 
These conditions all modify the best treatment option to cure the patient, minimize the occurrence of resistance and decrease the duration of hospitalization, thus reducing costs [4].

The objectives of this article are to make an exhaustive literature review of VL treatment; to analyze the methodology and the results of the reviewed studies; to give treatment recommendations based on the leishmaniasis presentation form, country of origin and Leishmania species: and, finally, to stratify the strength of the recommendations on the basis of the Infectious Diseases Society of America (IDSA) grade classification.

\section{Methods}

At the Tropical Medicine Unit of Ramón y Cajal Hospital in Madrid, Spain, the medical literature was searched, using databases such as MEDLINE, EMBASE, the Web of Science and the Cochrane Library database. No limits were placed with respect to the date of publication. No language restrictions were imposed. The chosen search terms were 'visceral leishmaniasis' AND 'treatment' OR 'parenteral treatment' OR 'oral treatment' OR 'azole drugs' OR 'miltefosine' OR 'pentavalent antimonials' OR 'amphotericin B' OR 'liposomal amphotericin' OR 'pentamidine' OR 'paromomycin' OR 'combination therapy'. Other search terms were 'visceral leishmaniasis' AND OR 'HIV', 'L. infantum' OR 'L. donovani' AND 'treatment'.

Bibliographical references from the included studies were also reviewed. The reference sections of primary studies, narrative reviews and systematic reviews were examined to search for additional primary studies that might have been missed during the electronic search.

Initially, only clinical trials were selected, in order to obtain data with the highest-grade evidence. In the absence of good-quality evidence, a second review was conducted in order to obtain cure-rate information. Later searches included original articles where data on results and treatment regimens were shown, such as large case series and multicentre studies, and also case reports when relevant results were reported.

For each of the selected articles, the data that were collected and analysed were the methodology, treatment regimens (doses and duration), cure rates (always using the last cure rate reported after the longest period of follow-up; when not specified, the intention-to-treat cure rate is given; when data on the per-protocol cure rate is known, this is also reported), the country where the study was performed and the Leishmania species that was isolated (when they could not be identified, either those species mentioned by the authors as being most common in the area where the study was performed, or those based on data published by the World Health Organization (WHO) [7] or in other epidemiological studies [2] were used). Such data were summarized in tables for each of the leishmaniasis forms of presentation that were studied.

On the basis of the methodology and the results of the studies, treatment recommendations were outlined for each leishmaniasis presentation form, country of origin and Leishmania species. The strength of such recommendations was stratified on the basis of the IDSA grade classification (Table 1). In this system, the letters A-E signify the strength of the recommendation for or against a therapeutic measure, and the roman numerals I-III indicate the quality of evidence supporting the recommendation $[8,9]$. The strength of the recommendation was determined on the basis of several factors such as the number of studies performed, the methodology of the studies, the number of patients included, whether or not the specific Leishmania spp. was isolated, and the time of follow-up.
Table 1 Infectious Diseases Society of America (IDSA) grade classification

\begin{tabular}{ll}
\hline $\begin{array}{l}\text { Category and } \\
\text { grade }\end{array}$ & Definition \\
\hline Strength of recommendation \\
A & Good evidence to support a recommendation for use \\
B & Moderate evidence to support a recommendation for use \\
C & Poor evidence to support a recommendation \\
D & Moderate evidence to support a recommendation against use \\
E & Good evidence to support a recommendation against use \\
Quality of evidence & \\
I & Evidence from one or more randomized clinical trials \\
II & Evidence from one or more well designed clinical trials, without randomization; from \\
& cohort or case-controlled analytic studies (preferably from $>1$ centre); from multiple \\
time series; or from dramatic results from uncontrolled experiments
\end{tabular}




\section{Treatment of Visceral Leishmaniasis}

\subsection{Monotherapy}

Studies of monotherapy for visceral leishmaniasis are listed in Table 2.

\subsubsection{Oral Treatment}

3.1.1.1 Allopurinol and Azole Drugs (Fluconazole, Ketoconazole, Itraconazole) The experience in the treatment of VL with allopurinol is scarce, out of date and has yielded disparate results. It is based on series of cases where allopurinol was used mainly as a rescue treatment in combination with antimonials or azole drugs [10-12].

The efficacy of treatment with azole drugs (fluconazole, ketoconazole, itraconazole) was based on uncontrolled studies with discordant results $[13,14]$. The occurrence of nephrotoxicity due to the combination of allopurinol and ketoconazole was rare, and this enabled them to be used with good results in renal transplant patients $[10,15,16]$.

In conclusion, there is little evidence to recommend the use of azole drugs or allopurinol in the treatment of VL. GRADE: CIII

3.1.1.2 Miltefosine Several clinical trials conducted 5-10 years ago showed good evidence of efficacy with miltefosine in VL in adults in India. Regimens of $2.5 \mathrm{mg} / \mathrm{kg} /$ day for 28 days have led to cure rates of 94-97 \% [17, 18]. Some studies have demonstrated that shorter regimens can also be effective; however, those results cannot be generalized, because of the small numbers of cases included and the absence of severe cases in those studies [19]. Similar results in children aged $<12$ years have been published [20,21], showing the same efficacy as that of amphotericin B deoxycholate in both newly treated and sodium stibogluconate-resistant patients [22]. Therefore, miltefosine was proposed as a first-line drug for VL in India, Nepal and Bangladesh.

However, a single-group trial performed in 2011 in Bangladesh, which included both adults and children, achieved cure rates of $85 \%$ with the standard miltefosine regimen [23]. Another non-comparative study performed in 2012 in 567 adults treated with miltefosine in India showed a cure rate of $90.3 \%$ at 6-month follow-up [24].

Initially, development of miltefosine-resistant parasites was thought to be the reason for this decrease in the cure rates. In fact, resistance to miltefosine has been shown to be easily induced in vitro $[25,26]$. However, two recent studies performed in Nepal and India in patients with VL treated with miltefosine showed similar in vitro miltefosine susceptibility (using an in vitro promastigote assay) in cured patients and in patients who relapsed [27, 28].
Moreover, in the Nepal study, the only significant risk factor that was found to be associated with relapse was age $<12$ years, probably due to differences in children's immune response, drug pharmacokinetics, and exposure to antigens. Another relevant fact was that the relapse rates were $10 \%$ at 6-month follow-up and $20 \%$ at 12-month follow-up. Considering that most clinical trials report 6-month follow-up, these findings also highlight the need for a longer follow-up period to establish a cure rate for miltefosine [27].

A clinical trial performed in Ethiopia in immunocompetent patients reported a $75.6 \%$ cure rate [29]. Reliable data on the efficacy of miltefosine in VL in the Mediterranean region and Latin America have not been published.

\begin{tabular}{|c|c|}
\hline \multicolumn{2}{|c|}{ Recommendation } \\
\hline Miltefosine regimen & Grade \\
\hline $\begin{array}{l}\text { Miltefosine (orally) for } 28 \text { days: } \\
2.5 \mathrm{mg} / \mathrm{kg} / \text { day in } \\
\text { children aged } 2-11 \text { years; } \\
50 \mathrm{mg} / \text { day in those aged } \\
\geq 12 \mathrm{years} \text { with bodyweight } \\
<25 \mathrm{~kg} ; 100 \mathrm{mg} / \text { day in } \\
\text { those aged } \geq 12 \text { years with } \\
\text { bodyweight } \geq 25 \mathrm{~kg} ; \\
150 \mathrm{mg} / \text { day in those aged } \\
\geq 12 \text { years with bodyweight } \\
>50 \mathrm{~kg}\end{array}$ & $\begin{array}{l}\text { AI: VL in the Indian } \\
\text { subcontinent, caused by } \\
\text { L. donovani } \\
\text { BI: VL in East Africa, caused by } \\
\text { L. donovani } \\
\text { CIII: VL in the Mediterranean } \\
\text { Basin and South America, } \\
\text { caused by } L \text {. infantum }\end{array}$ \\
\hline
\end{tabular}

\subsubsection{Parenteral Treatment}

3.1.2.1 Pentavalent Antimonials Sodium stibogluconate $\left(100 \mathrm{mg} \mathrm{Sb}{ }^{\mathrm{v}+} / \mathrm{mL}\right)$ and meglumine antimoniate $(85 \mathrm{mg}$ $\mathrm{Sb}^{\mathrm{v}+} / \mathrm{mL}$ ) are the two available formulations containing pentavalent antimonials.

They are currently considered the first-line drugs in different parts of the world, except in those zones where resistance has developed-fundamentally in the state of Bihar (India), where the resistance rates are approaching $60 \%$ of all cases [30].

The doses and durations of treatment regimens with antimonials have undergone constant changes over the years. Sodium stibogluconate was introduced in the late 1940s, becoming the first-line treatment for VL. It was initially administered at low doses of $10 \mathrm{mg} / \mathrm{kg} / \mathrm{day}$ for 6-10 days [31], but the occurrence of therapeutic failures required progressive increases in the dose and duration of treatment. In the 1980s, the first studies were done to determine the most effective dose [32,33] and, on the basis of those studies, the WHO decided in 1982 that the daily dose should be increased to $20 \mathrm{mg} \mathrm{Sb}{ }^{\mathrm{v}+} / \mathrm{kg}$ but specified 


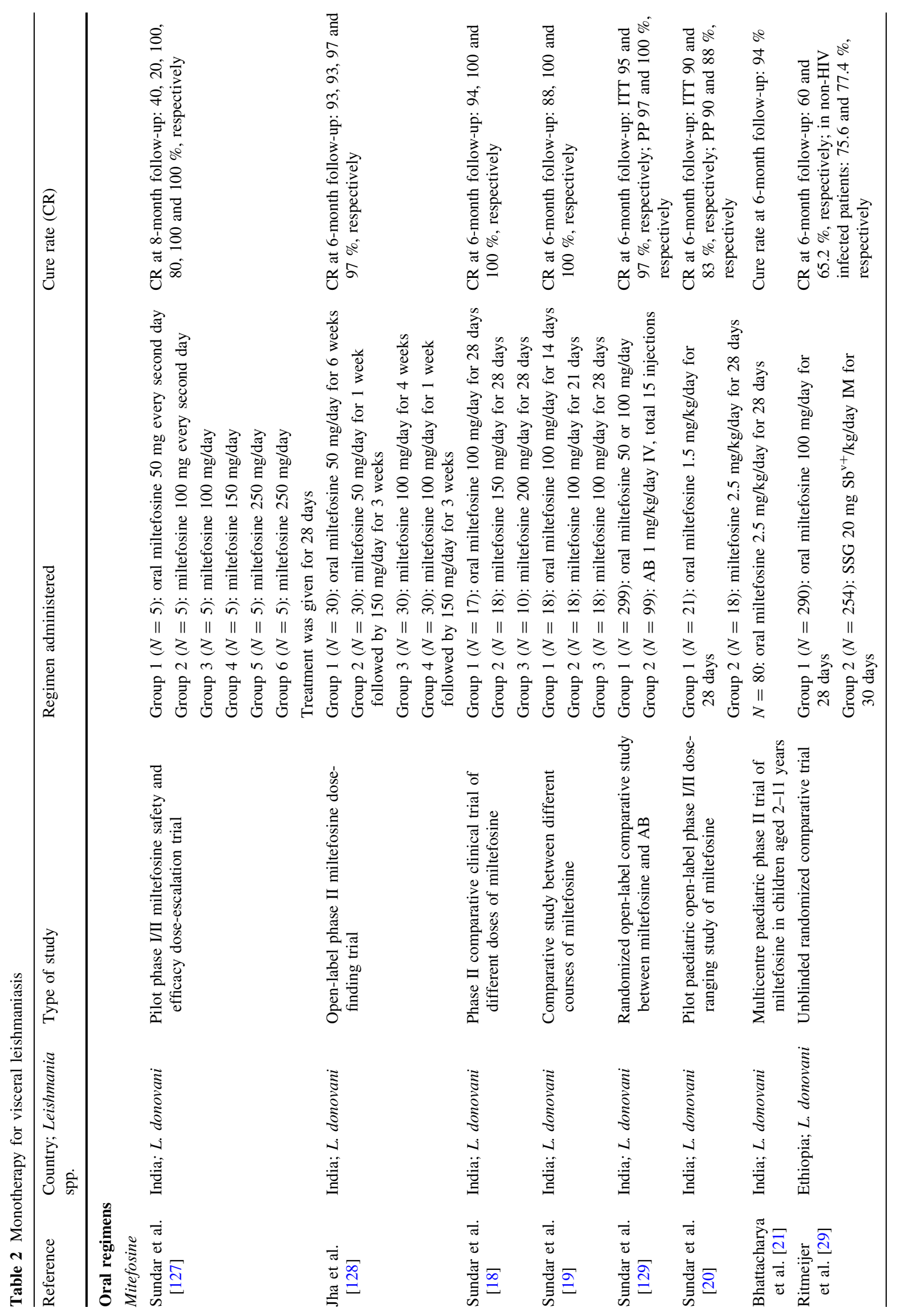




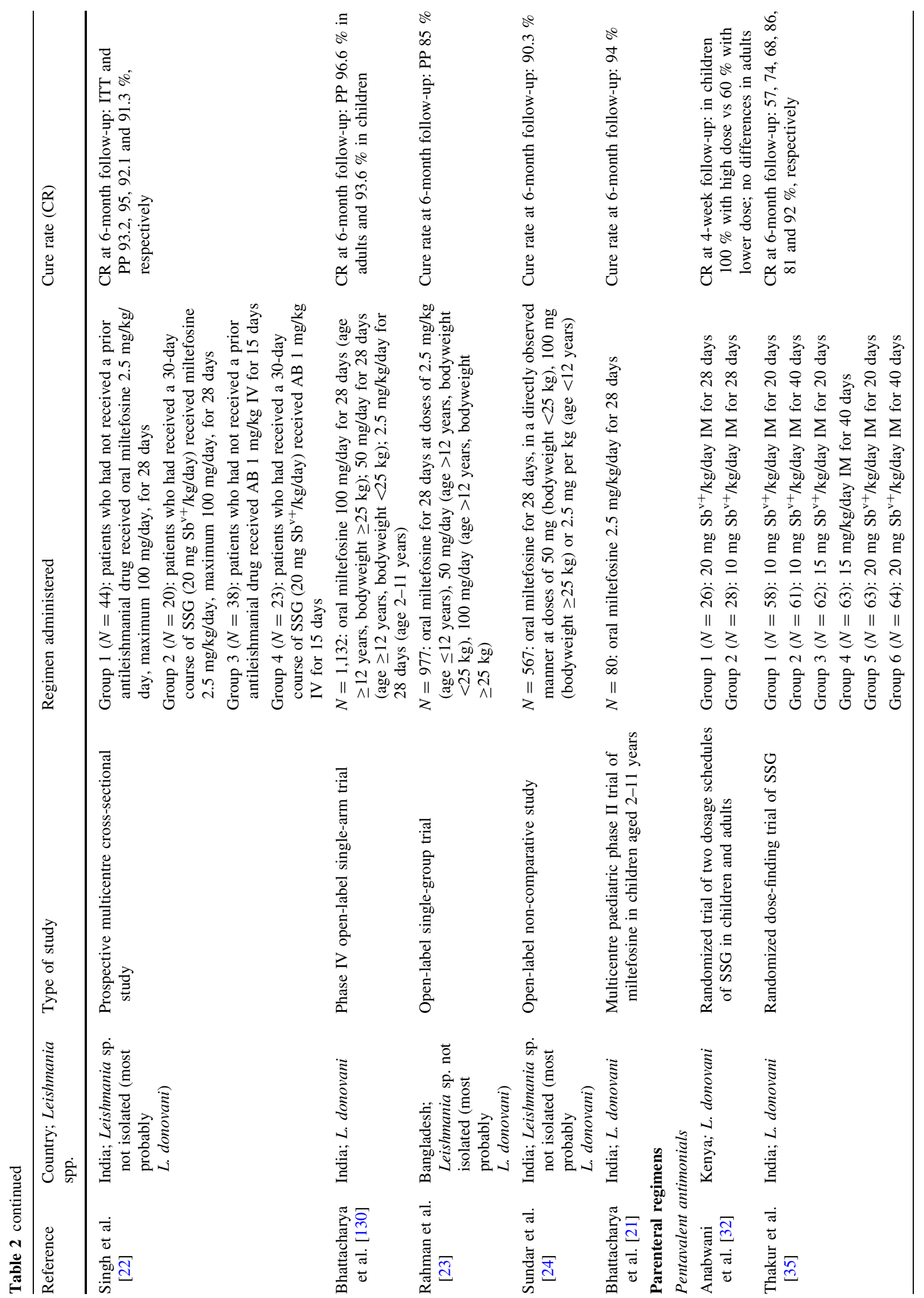




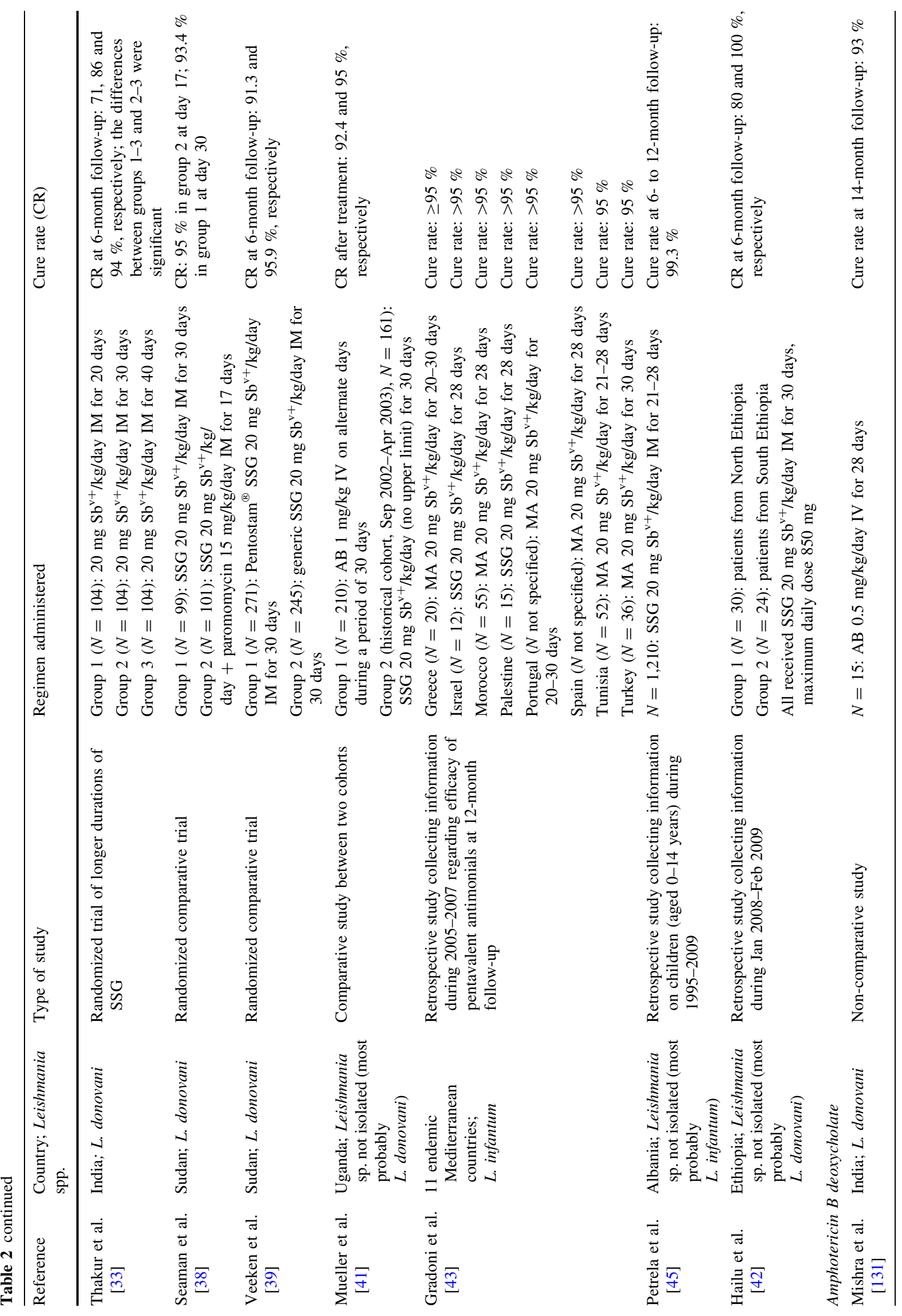




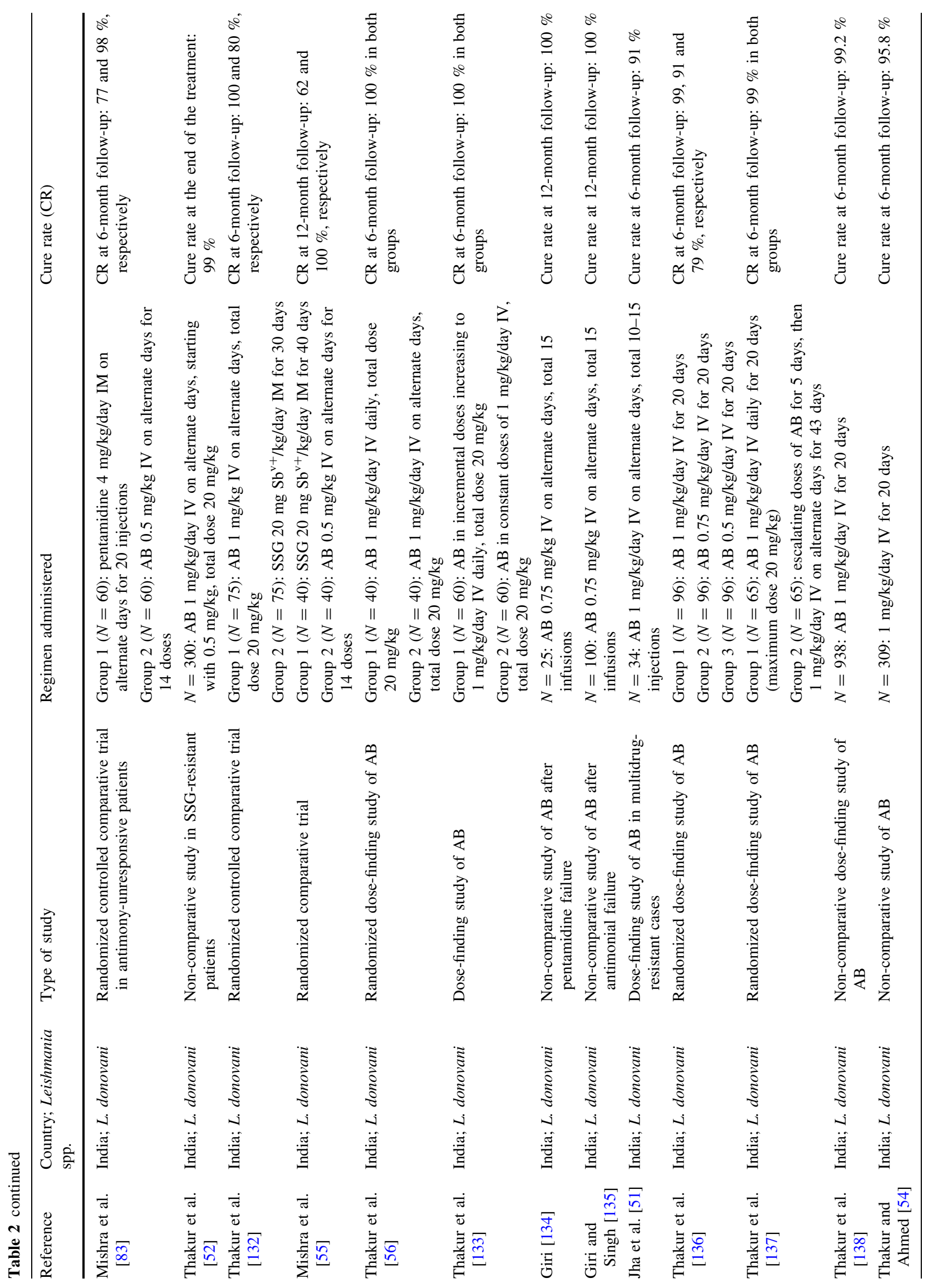




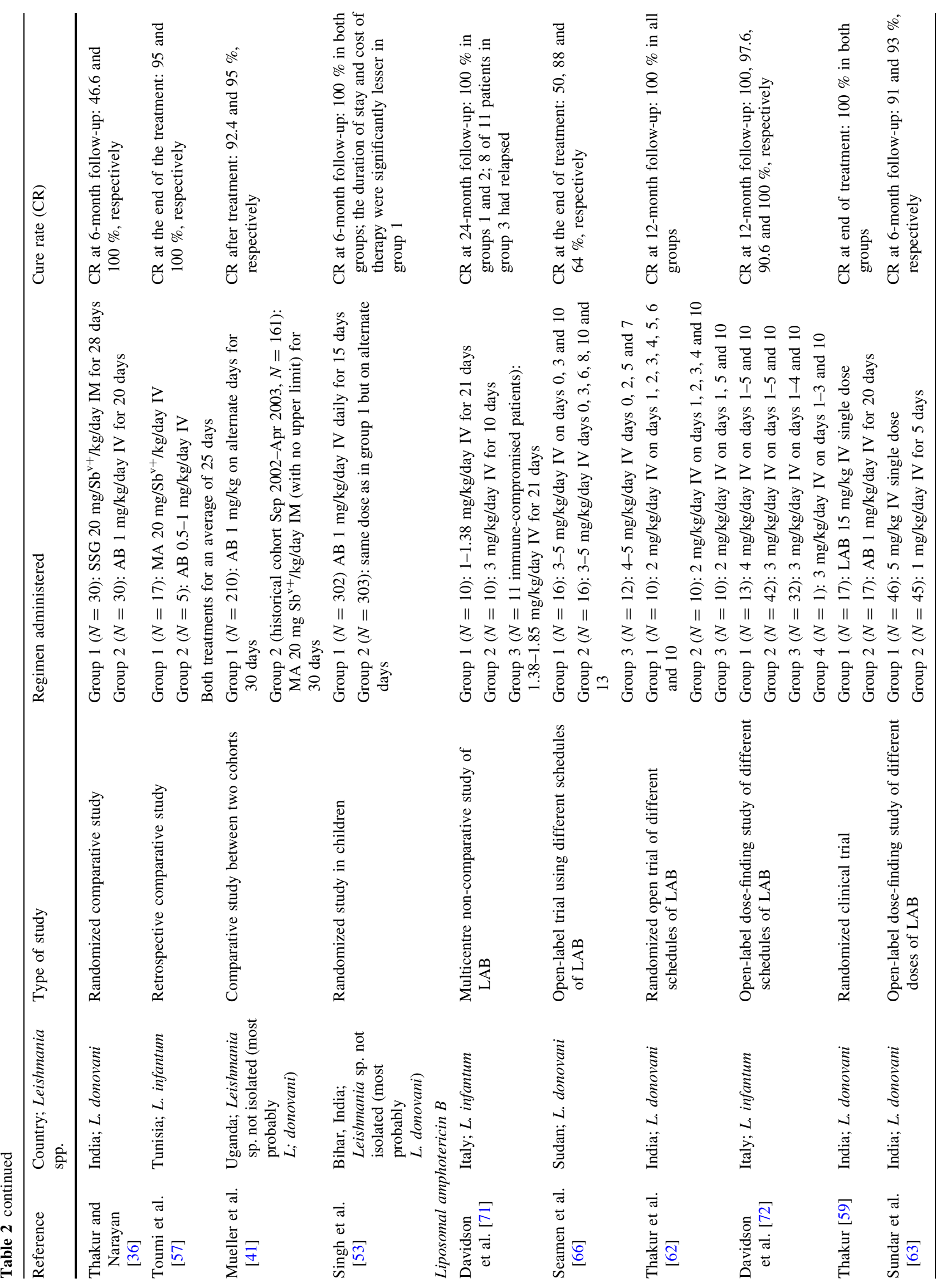




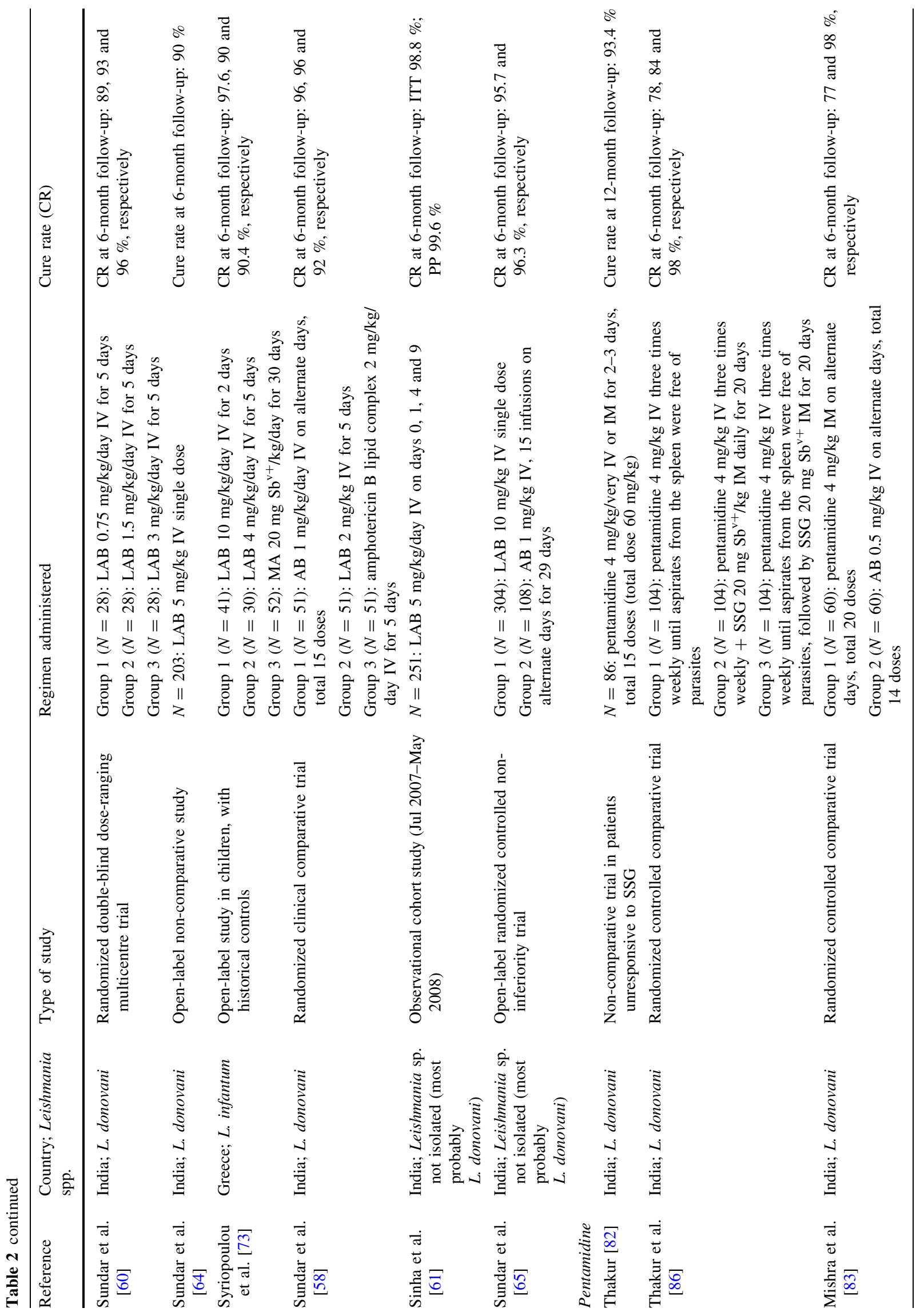




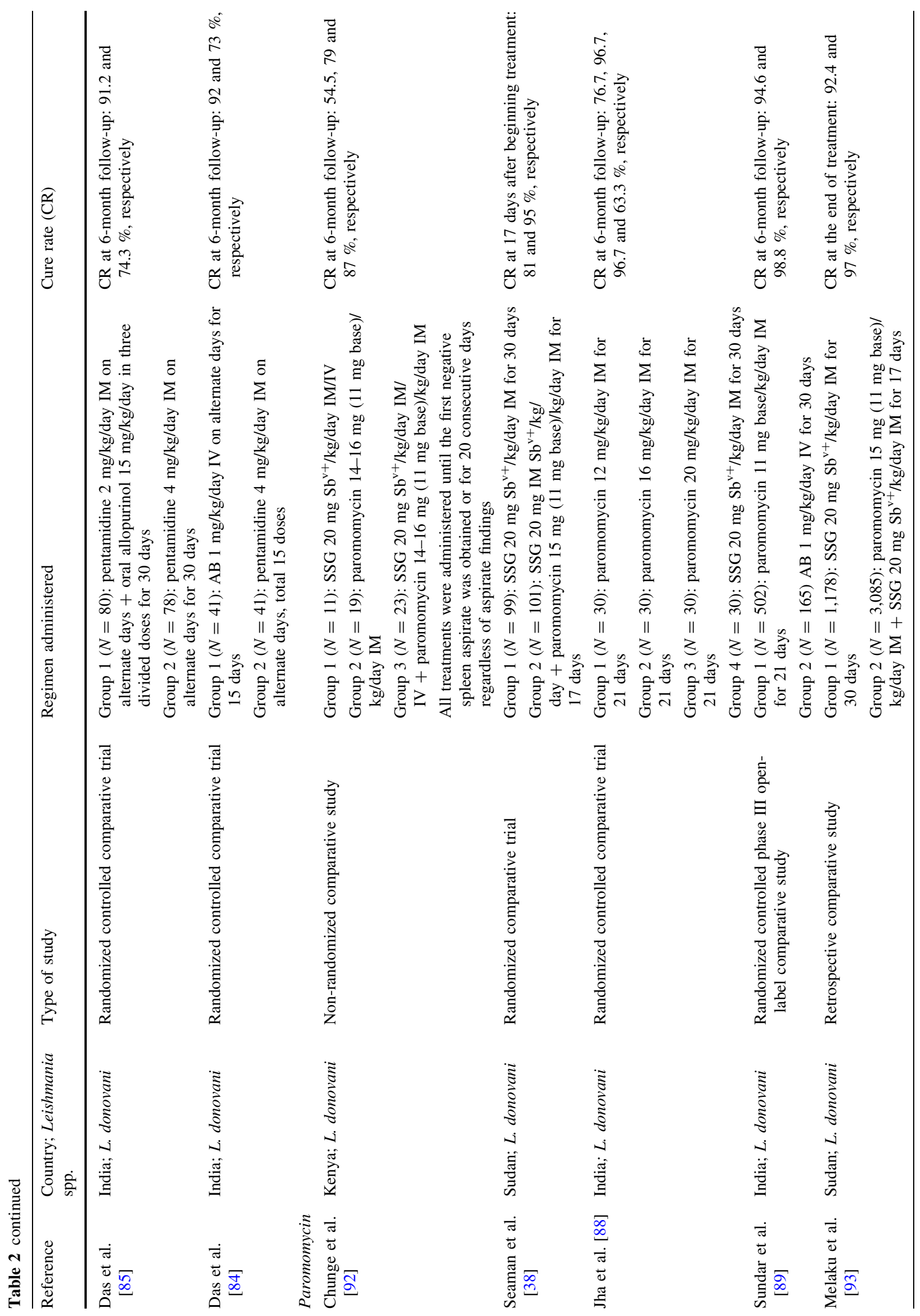




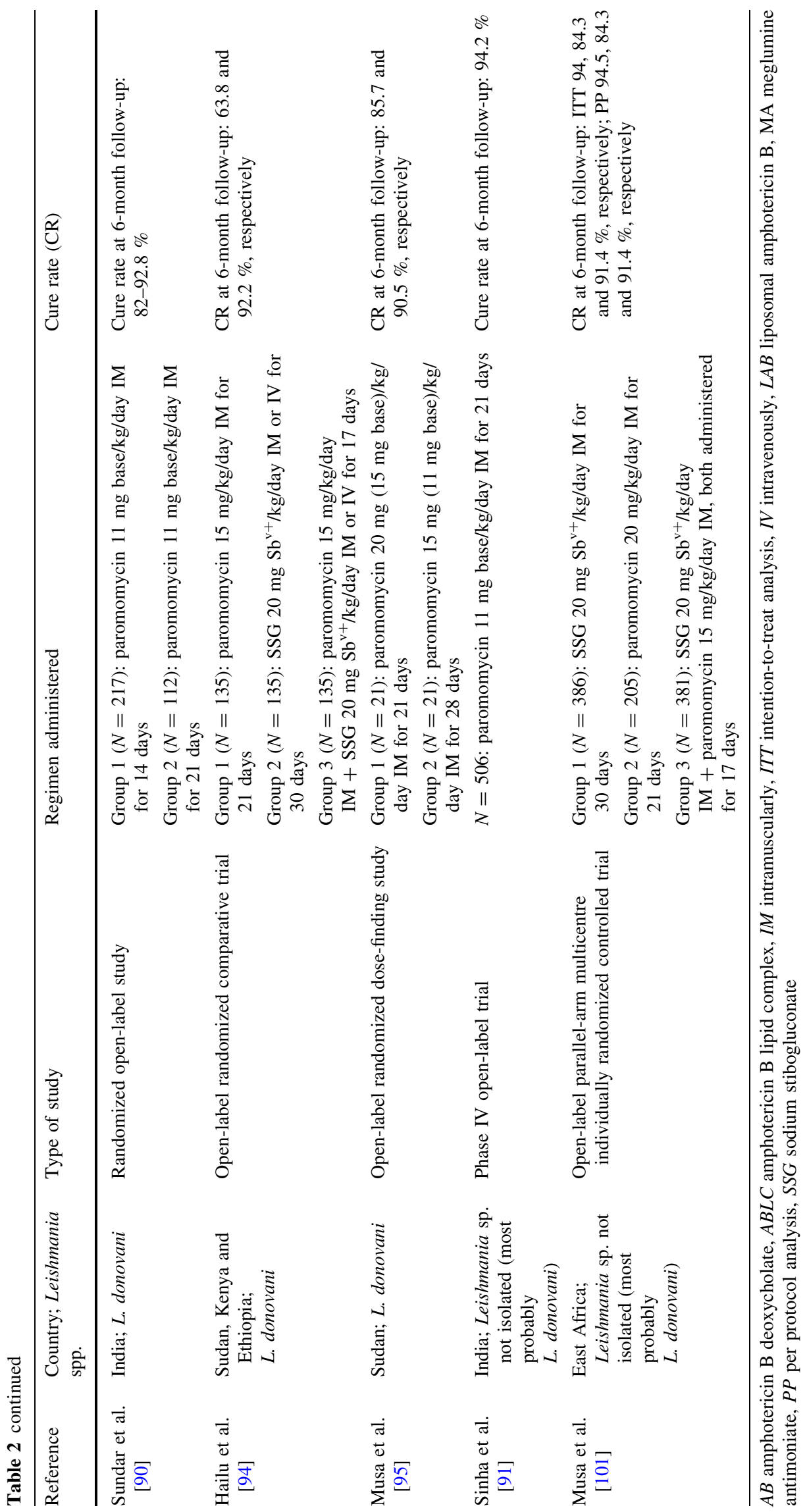


that the total daily dose should not exceed $850 \mathrm{mg}$ [34]. The choice of this limit was exclusively based on the quantity of $\mathrm{Sb}^{\mathrm{v}+}$ contained in two Glucantime ${ }^{\circledR}$ vials (each vial contains $5 \mathrm{~mL}$ with $85 \mathrm{mg} \mathrm{Sb}{ }^{v+} / \mathrm{mL}$ ) and on the fact that patient bodyweight did not exceed $45 \mathrm{~kg}$ in the studies that were initially reported [32]. Despite the fact that this recommendation was for $\mathrm{VL}$, it was also used for the treatment of other clinical forms of leishmaniasis. However, some studies were published in which it was argued that doses of greater than $850 \mathrm{mg} \mathrm{Sb}{ }^{\mathrm{v}+}$ per day were more effective [35]. Regarding the duration of the treatment, the first studies increased the regimens to 20,30 and 40 days $[32,33]$. Despite the fact that longer treatments (40 days) had better response rates and fewer relapses, toxicity was not taken into account. However, treatment regimens of $>28$ days resulted in cardiotoxicity rates of 8-17\% [36]. Thus, in 1992, the final recommendation was parenteral (IM or intravenous [IV]) administration of $20 \mathrm{mg} \mathrm{Sb}{ }^{\mathrm{v}+} / \mathrm{kg}$ without a limit of $850 \mathrm{mg} /$ day, for 28-30 days [37].

In Africa, the first trials were undertaken in Kenya in 1983 and marked a watershed in the determination of the optimal dose of pentavalent antimonials [32]. However, few new studies have been done since then. In the 1990s, a comparative study was performed in Sudan between sodium stibogluconate on its own versus sodium stibogluconate combined with paromomycin, with response rates that were higher with the combined treatment [38]. Other studies in Kenya and Sudan have analysed the efficacy of generic sodium stibogluconate versus patented versions, without observing any significant differences [39, 40]. Indeed, the generic formulae, which have a lower cost, have allowed health authorities to administer the treatment to more people in defined endemic zones in Africa, which have low resources. In Uganda, a comparative study was done between a cohort of patients treated with amphotericin B deoxycholate and a historic cohort of patients treated with antimonials at a dose of $20 \mathrm{mg} \mathrm{Sb} b^{\mathrm{v}} / \mathrm{kg} /$ day without imposing a limit, with response rates of $95 \%$ upon finishing the treatment [41]. A recent study conducted in Ethiopia demonstrated differences in the cure rates after 6 months between patients from the North and those from the South ( 80 versus $100 \%$ ), which was justified by the different rates of HIV co-infection (46.4\% of the patients from the North were HIV positive, while no HIV case was detected among patients from the South). Thus, the efficacy of antimonials in Ethiopia in immunocompetent patients seems to be very high [42].

In the Mediterranean countries, VL is mainly produced by $L$. infantum. In this case, the therapeutic evidence is less solid, and within the same zone, therapeutic attitudes even vary from country to country. During the 1990s, antimonials were the first-line treatment in France, Greece, Italy, Malta, Spain, Portugal, Morocco, Algeria and Tunisia, with cure rates of $95 \%$ in immunocompetent patients [43]. However, the information collected from 11 countries in Southern Europe, Northern Africa and the Middle East in the 21st century reflect certain variations in treatment recommendations [44]. In Morocco, Tunisia, Turkey and Palestine, antimonials at a dose of $20 \mathrm{mg}$ $\mathrm{Sb}^{\mathrm{v}} / \mathrm{kg} / \mathrm{day}$ were the first-line treatment; in Portugal, Spain, Greece and Italy, antimonials and amphotericin B deoxycholate preparations were the two options for firstline treatment (although antimonials were not administered to patients with severe immunosuppression, and preparations of liposomal amphotericin B were recommended for treatment of relapses after antimonials); in France, Italy and Cyprus, liposomal amphotericin B was the first-line treatment, and relapses were treated with different regimens of the same drug. A recently published study collected a total of 1,210 cases of VL in children aged 0-14 years in Albania from 1995 to 2009, and demonstrated that antimonials at a dose of $20 \mathrm{mg} \mathrm{Sb}^{\mathrm{v}+}$ $\mathrm{kg} /$ day for $21-28$ days continue to be effective, with a cure rate of $99 \%$ [45].

VL in the New World is produced by L. infantum/ chagasi. One of the most affected zones is the north-east of Brazil, where 3,000-5,000 cases appear every year, usually at a young age [46]. It is a zoonotic infection resulting in a high percentage of asymptomatic patients, in contrast to VL in India. Classically, the treatment of VL in Brazil was based on the use of antimonials, with a cure rate of up to $95 \%$, keeping amphotericin B deoxycholate as a second-line treatment [47]. The recent Pan-American Health Organization (PAHO) guidelines for the treatment of leishmaniasis in the Americas has established sodium stibogluconate as one of the first-line treatments at a dose of $20 \mathrm{mg} \mathrm{Sb}{ }^{\mathrm{v}+} / \mathrm{kg} /$ day IM or IV for 30 days [48].

\section{Recommendation}

\begin{tabular}{|c|c|}
\hline Pentavalent antimonial regimen & Grade \\
\hline \multirow{4}{*}{$\begin{array}{l}\text { Sodium stibogluconate } \\
\text { or meglumine antimoniate } \\
\text { (IM or IV) } 20 \mathrm{mg} \mathrm{Sb}^{\mathrm{v}+} / \mathrm{kg} / \mathrm{day} \\
\text { (upper limit } 850 \mathrm{mg} / \mathrm{day} \text { ) } \\
\text { for } 28-30 \text { days }\end{array}$} & $\begin{array}{l}\text { AI: VL in Bangladesh and Nepal } \\
\text { or in East Africa, caused by } \\
\text { L. donovani }\end{array}$ \\
\hline & $\begin{array}{l}\text { AII: VL in children in the } \\
\text { Mediterranean Basin, } \\
\text { caused by } L \text {. infantum }\end{array}$ \\
\hline & $\begin{array}{l}\text { BII: VL in the Middle East and } \\
\text { South America, caused by } \\
\text { L. infantum }\end{array}$ \\
\hline & $\begin{array}{l}\text { EI: VL in India (except in } \\
\text { Jharkhand, West Bengal, } \\
\text { Uttar Pradesh states), caused } \\
\text { by } L \text {. donovani }\end{array}$ \\
\hline
\end{tabular}


3.1.2.2 Amphotericin B Deoxycholate Amphotericin B deoxycholate has been used for treatment of visceral and mucocutaneous leishmaniasis in the New World [49, 50]. However, it was not until the beginning of the 1990s that the first clinical trials were undertaken for the treatment of VL in the Old World (India). These demonstrated response rates of $98-100 \%[50,51]$ as first-line treatment, and $92 \%$ in those cases where antimonials had previously failed [51, 52]. In India, initially $99 \%$ of all patients responded to regimens of $1 \mathrm{mg} / \mathrm{kg} / \mathrm{day}$ given daily or on alternate days for up to 20 doses [53, 54]. Later, it was shown that it was also effective (with a cure rate of $100 \%$ ) at lower doses of $0.5 \mathrm{mg} / \mathrm{kg} / \mathrm{day}$, given on alternate days for up to 14 days [55].

Later studies demonstrated that daily administration was equally tolerated and was as effective as administration on alternate days $[53,56]$. Because of the high rate of resistance to antimonials in India, amphotericin B deoxycholate seems to be established nowadays as the first-line treatment.

However, in other geographical areas with low resistance to antimonials, the use of amphotericin B deoxycholate is not as widespread. In fact, in Europe, lipid preparations of amphotericin B are used as first-line treatment or in those cases where antimonials have previously failed [44]. In Uganda, a cure rate of $92.4 \%$ was obtained with amphotericin B deoxycholate at a dose of $1 \mathrm{mg} / \mathrm{kg}$ on alternate days for a period of 30 days, similar to the cure rate in a historical cohort treated with antimonials and without any difference in the occurrence of severe side effects [41]. A retrospective study of five cases of VL in Tunisia treated with amphotericin B deoxycholate at a dose of $0.5-1 \mathrm{mg} / \mathrm{kg} /$ day for an average of 25 days obtained a $100 \%$ response rate [57].

The PAHO guidelines for the treatment of leishmaniasis in the Americas have established amphotericin B deoxycholate (1 mg/kg/day IV up to an $800 \mathrm{mg}$ total dose) as one first-line drug [48].

3.1.2.3 Liposomal Amphotericin B In India, at least 10 different regimens of liposomal amphotericin $B$ have been tested and resulted in a diverse range of response rates [58, 59]. Administration regimens of 5 days with total doses of $3.75,7.5$ and $15 \mathrm{mg} / \mathrm{kg}$ have been tested, with response rates that increase in proportion to the dose: 89, 93 and $96 \%$, respectively [60]. Regimens of a total dose of $20 \mathrm{mg} / \mathrm{kg}$ spread over 4 days have obtained a $98.8 \%$ cure rate [61]. However, another study found no differences between different dosages of $2 \mathrm{mg} / \mathrm{kg} /$ day for 7,5 and 3 days, obtaining a cure rate of $100 \%$ [62]. There have also been tests with different regimens of a single dose with good results. One study compared a single dose of $5 \mathrm{mg} / \mathrm{kg}$ versus administration over 5 days, with cure rates of 90 and
$93 \%$, respectively [63]. Another study compared liposomal amphotericin B in a single dose of $15 \mathrm{mg} / \mathrm{kg}$ versus amphotericin B deoxycholate in a dose of $1 \mathrm{mg} / \mathrm{kg} /$ day for 20 days, with $100 \%$ cure rates in both groups at the end of treatment [59]. Likewise, other non-comparative studies found that a single dose of $7.5 \mathrm{mg} / \mathrm{kg}$ achieved cure rates of $96 \%$ [64]. More recently, another study demonstrated that a single dose of $10 \mathrm{mg} / \mathrm{kg}$ was as effective as the conventional regimen of amphotericin B deoxycholate, with response rates of 95.7 and $96.3 \%$, respectively [65].

There is very little experience of liposomal amphotericin B in Eastern Africa, and the recommendations are based on results obtained in India. In Sudan, a total dose of $20 \mathrm{mg} / \mathrm{kg}$ was tested, with cure rates of $88 \%$, but a lower dose of $12 \mathrm{mg} / \mathrm{kg}$ obtained only a $50 \%$ response rate [66]. A later study, also performed in Sudan, supported the previous results in which a relatively high total dose of liposomal amphotericin B (15-49 mg/kg) was needed to cure Sudanese patients [67]. However, in both studies, most of the patients had high parasite density, had previously relapsed or suffered other severe underlying diseases such as HIV or tuberculosis. A phase II clinical trial in Kenya demonstrated efficacy of $20 \%$ with total doses of $6 \mathrm{mg} / \mathrm{kg}, 90 \%$ with total doses of $10 \mathrm{mg} / \mathrm{kg}$ and $100 \%$ with total doses of $14 \mathrm{mg} / \mathrm{kg}$ [68]. More recently, a case was reported of a Kenyan immigrant in Australia who travelled to visit friends and relatives and who responded to liposomal amphotericin B at a total dose of $20 \mathrm{mg} / \mathrm{kg}$ over 5 days [69]. Currently, a randomized, multicentre, noninferiority clinical trial is being conducted in Eastern Africa. It aims to compare a multiple-dose regimen with a total dose of $21 \mathrm{mg} / \mathrm{kg}$ given as $3 \mathrm{mg} / \mathrm{kg}$ IV on days $1,2,3$, 4, 5, 14 and 21, and expects to obtain $95 \%$ efficacy with a single-dose regimen. On the basis of the previous experience in India and Kenya [59, 64, 65], the trial will begin with a $7.5 \mathrm{mg} / \mathrm{kg}$ single-dose regimen and, if this regimen is found to be ineffective at the time of an interim analysis, patients will be re-randomized to receive a higher dose (10, $12.5 \mathrm{mg} / \mathrm{kg}$ up to a maximum of $15 \mathrm{mg} / \mathrm{kg}$ ) [70]. Thus, it is expected that higher doses are needed in Eastern Africa than in India.

In Southern Europe, doses of 3-5 mg/kg/day, up to a total of $20 \mathrm{mg} / \mathrm{kg}$ in different regimens, have been demonstrated to be effective in up to $99-100 \%$ of patients [71]. Total doses of 15,18 and $24 \mathrm{mg} / \mathrm{kg}$ were tested in Italy, with response rates of 91,98 and $100 \%$, respectively [72]. In Greece, one study administered a total dose of $20 \mathrm{mg} / \mathrm{kg}$ in a short regimen of 2 days, with a cure rate of $98 \%$, versus $90 \%$ when it was administered over 5 days [73]. Because of the large number of published case series, there is an important accumulation of evidence regarding the use of liposomal amphotericin B in pediatric populations in Europe, with response rates $>97 \%$ with total doses 
of $18-24 \mathrm{mg} / \mathrm{kg}$ in different regimens $[74,75]$. It has been shown that liposomal amphotericin $\mathrm{B}$ reduces the average duration of hospitalization when compared with antimonials [76] and that it was effective in those cases where antimonials had previously failed [77] For all of these reasons, and despite the absence of randomized clinical trials, liposomal amphotericin B is considered a reference treatment in the case of VL in the Mediterranean countries in adults as well as in children [78].

In Latin America, there is much less evidence. In Brazil, doses of $20 \mathrm{mg} / \mathrm{kg}$ have been proven to be effective [68]. In Colombia, two cases were published, where treatment with antimonials had failed, but both cases responded to liposomal amphotericin $\mathrm{B}$ at a dose of $2 \mathrm{mg} / \mathrm{kg} /$ day for 21 days in one patient, and a dose of $0.6 \mathrm{mg} / \mathrm{kg} / \mathrm{day}$ for 15 days in the other [79]. The PAHO guidelines for treatment of leishmaniasis in the Americas have established liposomal amphotericin B (3-5 mg/kg/day IV for 3-6 days, with a total dose of $20 \mathrm{mg}$ ) as one of the first-line therapeutic options [48].

\subsubsection{Other Lipid Preparations of Amphotericin B}

There is little evidence about the other different lipid preparations of amphotericin B deoxycholate. In India, the efficacy of amphotericin B lipid complex was compared with those of amphotericin B deoxycholate and liposomal amphotericin B, without encountering any significant differences [58].

Despite the efficacy of lipid preparations, especially highlighted by liposomal amphotericin B, and their lower toxicity than that of amphotericin B deoxycholate, they have the disadvantage of high cost, which is particularly important in low-income countries. However, some lowincome countries in the Indian subcontinent (Bangladesh, Nepal) and in East Africa (Sudan, South Sudan, Ethiopia and Kenya) would have access to reduced-price liposomal amphotericin B (AmBisome) through the Gilead/WHO AmBisome donation programme. An attempt has been made to develop inexpensive lipid-containing amphotericin B deoxycholate by mixing it with commercially available lipid emulsions. A commercial standardized product of pre-formed amphotericin B lipid emulsion is licensed for use in VL in India, after obtaining a cure rate of $91.1 \%$ with total doses of $9-15 \mathrm{mg} / \mathrm{kg}$ [80]. A subsequent study comparing four different administration regimens of a $15 \mathrm{mg} / \mathrm{kg}$ total dose of amphotericin B lipid emulsion obtained not only good results in terms of the safety of the drug, but also cure rates of $100 \%$ in patients who received a single dose of $15 \mathrm{mg} / \mathrm{kg}$ [81]. Thus, administering amphotericin B lipid emulsion at a total dose of $15 \mathrm{mg} / \mathrm{kg}$ IV over $4 \mathrm{~h}$ in a single dose or spreading it over a daily dose of $5 \mathrm{mg} / \mathrm{kg}$ for three consecutive days is very effective $(100 \%)$ for the treatment of VL in India, caused by $L$. donovani. GRADE BII

\section{Recommendation}

\begin{tabular}{|c|c|}
\hline Regimen & Grade \\
\hline \multicolumn{2}{|l|}{ Amphotericin B deoxycholate } \\
\hline $\begin{array}{l}\text { Amphotericin B deoxycholate } \\
\text { (IV) } 0.7-1 \mathrm{mg} / \mathrm{kg} / \mathrm{day} \text {, on } \\
\text { alternate days, for } 15-20 \\
\text { doses }\end{array}$ & $\begin{array}{l}\text { AI: VL in the Indian } \\
\text { subcontinent, caused by } \\
\text { L. donovani } \\
\text { BII: VL in East Africa, caused by } \\
\text { L. donovani } \\
\text { BIII: VL in the Mediterranean } \\
\text { Basin and Latin America, } \\
\text { caused by } L \text {. infantum }\end{array}$ \\
\hline \multicolumn{2}{|l|}{ Liposomal amphotericin $B$} \\
\hline $\begin{array}{l}\text { (Regimen 1) liposomal } \\
\text { amphotericin B (IV) } \\
10 \mathrm{mg} / \mathrm{kg} \text { for } 1 \text { or } 2 \text { doses }\end{array}$ & $\begin{array}{l}\text { AI: (regimen } 1 \text { or regimen } 2 \text { ): VL } \\
\text { in the Indian subcontinent, } \\
\text { caused by } L \text {. donovani }\end{array}$ \\
\hline $\begin{array}{l}\text { (Regimen 2) liposomal } \\
\text { amphotericin B (IV) } \\
3-5 \mathrm{mg} / \mathrm{kg} / \text { day for } 3-5 \\
\text { doses (total dose } 15 \mathrm{mg} / \mathrm{kg} \text { ) }\end{array}$ & $\begin{array}{l}\text { AII: (regimen } 3 \text { in adults and } \\
\text { regimen } 2 \text { in children): VL } \\
\text { in the Mediterranean Basin, } \\
\text { caused by } L \text {. infantum }\end{array}$ \\
\hline $\begin{array}{l}\text { (Regimen 3) liposomal } \\
\text { amphotericin B (IV) } \\
3-5 \mathrm{mg} / \mathrm{kg} / \text { day for } 3-10 \\
\text { doses (total dose } \\
18-30 \mathrm{mg} / \mathrm{kg} \text { ) }\end{array}$ & $\begin{array}{l}\text { BII: (regimen 4): VL in East } \\
\text { Africa, caused by } \\
\text { L. donovani }\end{array}$ \\
\hline $\begin{array}{l}\text { (Regimen } 4 \text { ) liposomal } \\
\text { amphotericin B (IV) } \\
3-5 \mathrm{mg} / \mathrm{kg} / \text { day for } 6-10 \\
\text { doses (total dose } 30 \mathrm{mg} / \mathrm{kg} \text { ) }\end{array}$ & $\begin{array}{l}\text { CIII: (regimen } 3 \text { ): VL in South } \\
\text { America, caused by } \\
\text { L. infantum }\end{array}$ \\
\hline
\end{tabular}

3.1.2.5 Pentamidine When India faced the need to find alternatives to pentavalent antimonials, pentamidine was tested in VL-endemic areas. In the 1980s, pentamidine at a dose of $4 \mathrm{mg} / \mathrm{kg}$ three times weekly for 12-21 days had obtained a cure rate of $93 \%$ [82]. However, the response rate started to decrease after the 1990s to about $70-80 \%$ in certain areas of India [83]. Later studies compared it with other therapeutic options used in those areas, as is the case with amphotericin $\mathrm{B}$ deoxycholate, demonstrating that pentamidine was less effective [84]. Other studies revealed that the response rate increased when pentamidine was combined with antimonials or allopurinol $[85,86]$.

In Eastern Africa, pentamidine proved to be effective in the treatment of patients in Sudan after pentavalent antimonials had previously failed [87].

There is little literature about use of pentamidine in the Mediterranean area and Latin America. 
The decrease in its efficacy, its serious and sometimes irreversible toxicity, and the availability of other therapeutic options have meant that use of pentamidine has practically been abandoned over the last $4-5$ years.

\subsubsection{Paromomycin (Aminosidine) In the 1990s, dif-} ferent clinical trials were conducted, injecting paromomycin either alone or in combination with pentavalent antimonials as treatment for VL in India (Bihar) and in Africa (Kenya and Sudan).

In the state of Bihar (India), a phase II study was developed to evaluate the effectiveness and tolerability of paromomycin compared with antimonials. The patients treated with paromomycin achieved response rates of 77-97 \%, compared with $66 \%$ for antimonials. In addition to this, paromomycin showed a lower incidence of side effects, which included ototoxicity and renal toxicity. For this reason, it was concluded from this study that paromomycin was an adequate second-line treatment in cases resistant to antimonials [88]. These results led to the development of a phase III trial in Bihar from 2003 to 2004, where paromomycin was not inferior to amphotericin B deoxycholate, with final cure rates of 94.6 versus $98.8 \%$, respectively [89]. Recently, a study comparing the efficacy of paromomycin $15 \mathrm{mg}$ (11 mg base)/kg/day for 14 days versus 21 days reported the efficacy to be inferior at 14 days [90]. Finally, a phase IV study investigating the safety and efficacy of paromomycin in 506 adult and child patients attending six clinical centres in the state of Bihar has been published. All patients were treated for 21 days with paromomycin $11 \mathrm{mg}$ base $/ \mathrm{kg} /$ day IM. The cure rate after 6 months was $94.2 \%$, with good tolerability. With the exception of an increase in liver function test parameters, which decreased towards baseline over time, paromomycin had a reasonably safe profile, including demonstrated safety and efficacy in paediatric patients and, though with limited data, in pregnant women [91].

In Africa, the majority of studies performed have been based on comparisons between paromomycin and antimonials, or on a combination of both. In a study in Kenya, the cure rate of paromomycin at a dose of $11 \mathrm{mg}$ base $/ \mathrm{kg} /$ day (until obtaining a negative spleen puncture or until achieving 20 consecutive days of treatment) was $54.4 \%$ [92]. Later studies carried out in Sudan revealed that the addition of paromomycin to antimonials increased the cure rate to $95-97 \%$ [38, 93]. Furthermore, a study conducted in Sudan, Kenya and Ethiopia compared the efficacy of paromomycin as monotherapy at a dose of $15 \mathrm{mg}(11 \mathrm{mg}$ base) $/ \mathrm{kg} /$ day for 21 days, antimonials as monotherapy for 30 days or the combination of both for 17 days. An interim analysis showed that paromomycin monotherapy had efficacy of $<50 \% 6$ months after the end of treatment in Sudan. This treatment arm was discontinued, and the trial continued with a higher dose of paromomycin $20 \mathrm{mg} / \mathrm{kg} /$ day for 21 days. After 6 months, the overall response rates were $92.2 \%$ with sodium stibogluconate and $63.8 \%$ with paromomycin; however, the efficacy of paromomycin varied substantially between geographical areas, with cure rates of 14.3-46.7 \% in Sudan, $80 \%$ in Kenya and 75-96.6 \% in Ethiopia [94]. Faced with this low response in Sudan, a new comparative study was carried out with higher doses of paromomycin, either increasing the duration of treatment from 21 to 28 days or increasing the daily dose from 15 to $20 \mathrm{mg}$ base. Both options proved to be more effective than the usual regimen of $15 \mathrm{mg}(11 \mathrm{mg}$ base) $/ \mathrm{kg} / \mathrm{day}$ for 21 days, with cure rates of 81 and $80 \%$ with 15 and $30 \mathrm{mg} / \mathrm{kg} / \mathrm{day}$, respectively [95].

There are no data for the Mediterranean and Latin America (Table 2).

\section{Recommendation}

\begin{tabular}{|c|c|}
\hline Regimen & Grade \\
\hline \multicolumn{2}{|l|}{ Pentamidine } \\
\hline $\begin{array}{l}\text { Pentamidine isethionate (IM } \\
\text { or IV) } 4 \mathrm{mg} / \mathrm{kg} / \mathrm{day} \text { on } \\
\text { alternate days or three times } \\
\text { weekly for } 15-20 \text { doses }\end{array}$ & $\begin{array}{l}\text { DI: VL in the Indian } \\
\text { subcontinent, caused by } \\
\text { L. donovani } \\
\text { DIII: VL in East Africa, caused } \\
\text { by } L . \text { donovani; VL in the } \\
\text { Mediterranean Basin and } \\
\text { Latin America, caused by } \\
\text { L. infantum }\end{array}$ \\
\hline \multicolumn{2}{|l|}{ Paromomycin } \\
\hline $\begin{array}{l}\text { (Regimen 1) paromomycin } \\
\text { (IM) } 15 \mathrm{mg}(11 \mathrm{mg} \text { base }) / \\
\mathrm{kg} / \text { day for } 21 \text { days }\end{array}$ & $\begin{array}{l}\text { AI: (regimen } 1 \text { ): } \mathrm{VL} \text { in the Indian } \\
\text { subcontinent, caused by } \\
\text { L. donovani }\end{array}$ \\
\hline $\begin{array}{l}\text { (Regimen } 2 \text { ) paromomycin } \\
\text { (IM) } 15 \mathrm{mg}(11 \mathrm{mg} \text { base }) / \\
\mathrm{kg} / \text { day for } 28 \text { days or } \\
20 \mathrm{mg}(15 \mathrm{mg} \text { base }) / \mathrm{kg} / \text { day } \\
\text { for } 21 \text { days }\end{array}$ & $\begin{array}{l}\text { BI: (regimen 2): VL in East } \\
\text { Africa (Kenya and Ethiopia, } \\
\text { with a lower response rate in } \\
\text { Sudan), caused by } \\
\text { L. donovani }\end{array}$ \\
\hline
\end{tabular}

\subsection{Combination Therapy}

Combined therapy has the following objectives: shortening the duration of treatment (which leads to fewer side effects and improved adherence to the regimen), lowering the cost of the treatment, stopping the development of resistance, and encouraging a cure, especially in complicated cases (Table 3).

In India, one of several published studies regarding combined therapy was undertaken in patients who had not responded to pentavalent antimonials. It demonstrated favourable results in patients treated sequentially with pentamidine and antimonials [86]. Another similar study 


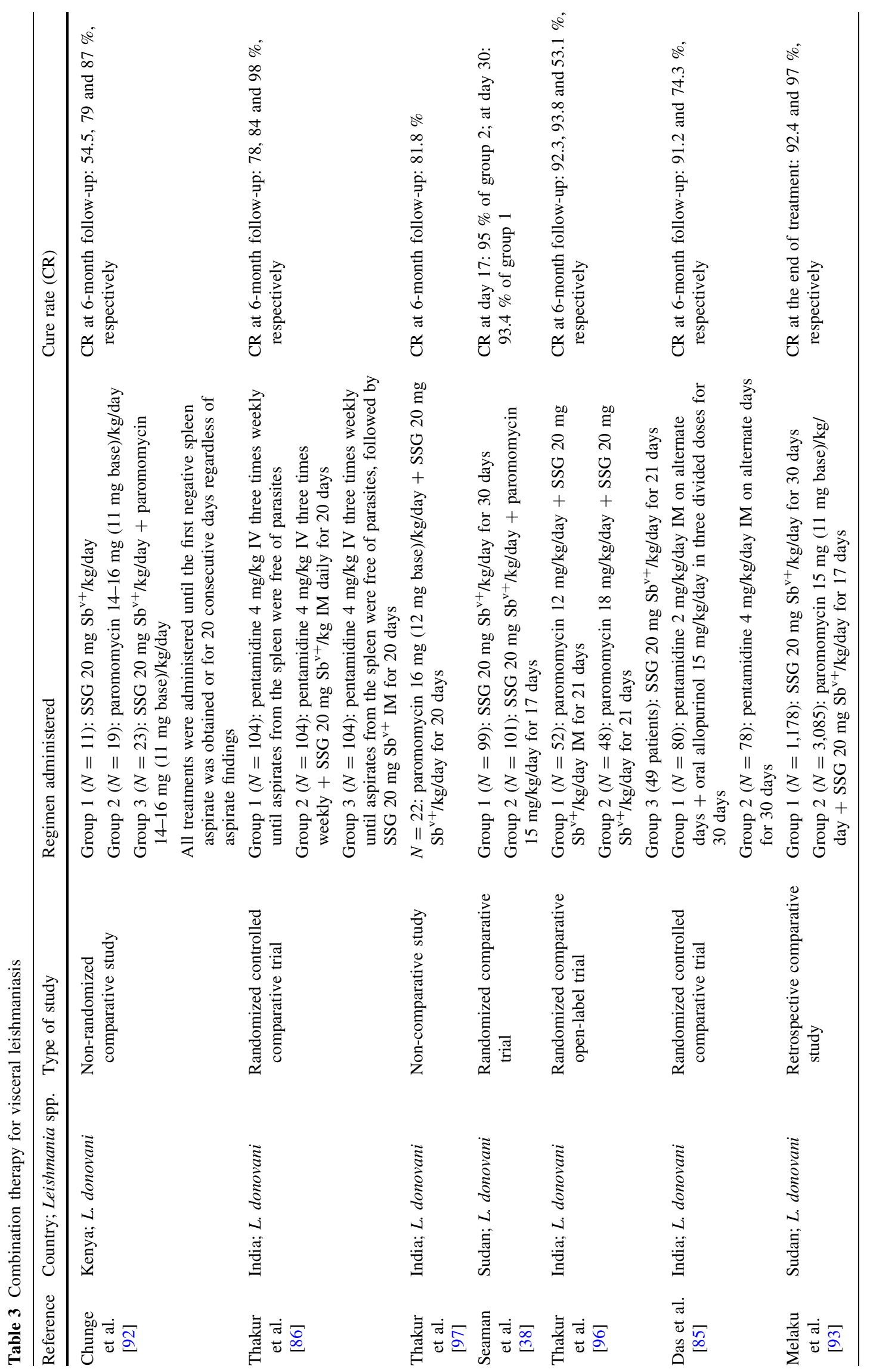




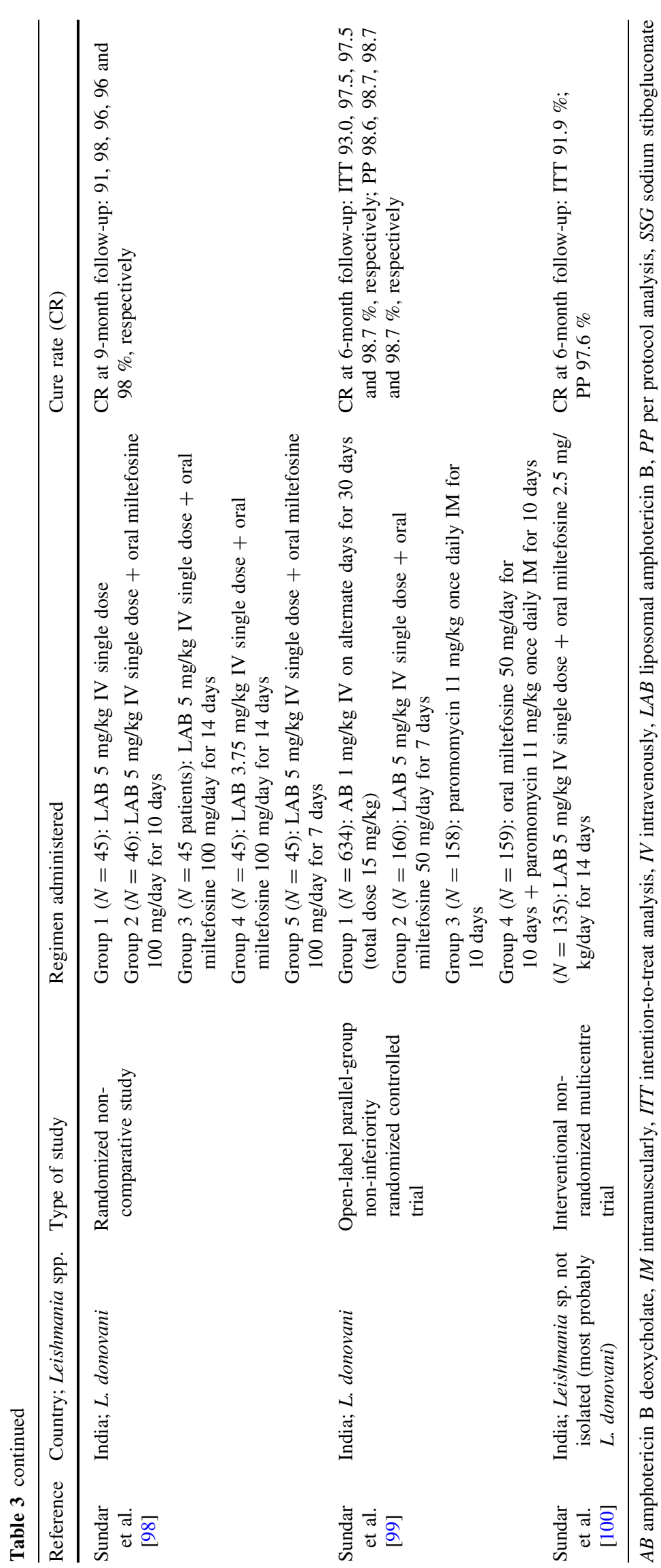


also underlined the positive effect of the combination of pentamidine and allopurinol [85]. Also, in India and in patients never treated before, the combination of paromomycin and antimonials administered in short regimens was more effective than the conventional and longer regimens of antimonials [96, 97]. A more recent study showed slightly greater efficacy with combinations of liposomal amphotericin B at $5 \mathrm{mg} / \mathrm{kg} /$ day in a single dose followed by different regimens of oral miltefosine, compared with liposomal amphotericin B at $5 \mathrm{mg} / \mathrm{kg} /$ day in a single dose (96-98 versus $91 \%$ ) [98]. In a comparative study performed in India, all drug combinations that were tested (single-dose liposomal amphotericin B plus miltefosine for 7 days or paromomycin for 10 days or miltefosine plus paromomycin for 10 days) were non-inferior to the standard treatment (amphotericin B deoxycholate for 30 days); patients in the combination groups had fewer adverse events than did those assigned to standard treatment [99]. Another recently published study, also carried out in India, assessed the combination of one single dose of liposomal amphotericin B $5 \mathrm{mg} / \mathrm{kg}$ and miltefosine $2.5 \mathrm{mg} / \mathrm{kg} / \mathrm{day}$ for 14 days, and found that the final intention-to-treat cure rate was $91.9 \%$, whereas per protocol it was $97.6 \%$ [100].

In Eastern Africa, specifically Sudan, two studies demonstrated that paromomycin associated with antimonials (sodium stibogluconate) increased the response rate in comparison with sodium stibogluconate as monotherapy [38, 93]. In Kenya, a non-randomized trial compared paromomycin and sodium stibogluconate as monotherapy versus the combination of both, the latter being the most effective option [92]. In a study performed in East Africa (Sudan, Ethiopia, Kenya and Uganda) monotherapy with paromomycin ( $20 \mathrm{mg} / \mathrm{kg} / \mathrm{day}$ for 21 days) or with sodium stibogluconate $(20 \mathrm{mg} / \mathrm{kg} /$ day for 30 days) was compared with combination therapy (paromomycin $15 \mathrm{mg} / \mathrm{kg} / \mathrm{day}$ and sodium stibogluconate $20 \mathrm{mg} / \mathrm{kg} /$ day for 17 days). Combination therapy was a safe regimen and just as effective (cure rate $91.4 \%$ ) as antimonials on their own (cure rate $93.9 \%$ ), thus being a good option for treatment in Eastern Africa [101].

A phase II, open-label, randomized, controlled clinical trial has recently been completed in East Africa; however, the results are yet to be published. The trial assessed whether a short combination of sodium stibogluconate $(20 \mathrm{mg} / \mathrm{kg} /$ day IM or IV for 10 days) plus a single dose of liposomal amphotericin B (10 mg/kg on day 1$)$, or oral miltefosine $(2.5 \mathrm{mg} / \mathrm{kg} / \mathrm{day}$ up to maximum of $150 \mathrm{mg}$ for 10 days, starting on day 2) plus a single dose of liposomal amphotericin B $(10 \mathrm{mg} / \mathrm{kg}$ on day 1$)$, or oral miltefosine alone ( $2.5 \mathrm{mg}$ oral up to maximum of $150 \mathrm{mg}$ for 28 days) are effective in treating VL in non-HIV patients [102].

\begin{tabular}{|c|c|}
\hline \multicolumn{2}{|c|}{ Recommendation } \\
\hline Combination regimen & Grade \\
\hline $\begin{array}{l}\text { (Regimen 1) liposomal } \\
\text { amphotericin B (IV) } 5 \mathrm{mg} / \mathrm{kg} \\
\text { single dose }+ \text { miltefosine } \\
\text { (orally) for } 7-14 \text { days: } 2.5 \\
\mathrm{mg} / \mathrm{kg} / \text { day in children aged } \\
2-11 \text { years; } 50 \mathrm{mg} / \text { day in those } \\
\text { aged } \geq 12 \text { years with } \\
\text { bodyweight }<25 \mathrm{~kg} ; 100 \mathrm{mg} / \text { day } \\
\text { in those aged } \geq 12 \text { years } \\
\text { with bodyweight } \geq 25 \mathrm{~kg} \text {; } \\
150 \mathrm{mg} / \text { day in those aged } \\
\geq 12 \text { years with bodyweight } \\
\geq 50 \mathrm{~kg} \\
\text { (Regimen } 2 \text { ) liposomal } \\
\text { amphotericin B (IV) } 5 \mathrm{mg} / \mathrm{kg} \\
\text { single dose }+ \text { paromomycin } \\
\text { (IM) } 15 \mathrm{mg}(11 \mathrm{mg} \text { base) } / \mathrm{kg} / \text { day } \\
\text { for } 10 \text { days } \\
\text { (Regimen } 3 \text { ) miltefosine (orally) } \\
\text { for } 10 \text { days: as } \\
\text { above }+ \text { paromomycin (IM) } \\
15 \mathrm{mg} \text { (11 mg base)/kg/day for } \\
10 \text { days } \\
\text { (Regimen } 4 \text { ) sodium } \\
\text { stibogluconate or meglumine } \\
\text { antimoniate (IM or IV) } 20 \mathrm{mg} \\
\mathrm{Sb} \mathrm{v} / \mathrm{kg} / \text { day for } 17 \text { days } \\
\text { (without an upper limit of } \\
850 \mathrm{mg} / \mathrm{day})+ \text { paromomycin } \\
\text { (IM) } 15 \mathrm{mg}(11 \mathrm{mg} \text { base) } / \mathrm{kg} / \text { day } \\
\text { for } 17 \text { days }\end{array}$ & $\begin{array}{l}\text { AI: (regimen } 1 \text { or regimen } \\
2 \text { or regimen } 3 \text { ): VL in } \\
\text { the Indian subcontinent, } \\
\text { caused by } L \text {. donovani } \\
\text { AI: (regimen } 4 \text { ): VL in East } \\
\text { Africa, caused by } \\
\text { L. donovani }\end{array}$ \\
\hline
\end{tabular}

\subsection{Therapy in HIV-Infected Patients}

Atypical forms of presentation and frequent relapses have been described in immunosuppressed patients. Immunoglobulin deficits, autoimmune diseases, tumours, organ transplants, or use of corticosteroids, methotrexate or tumour necrosis factor inhibitors can cause immunosuppression. Co-infection with HIV hinders the therapeutic response, causing relapses to be frequent, especially in patients with $\mathrm{CD}+$ cell counts $<200$ cells $/ \mu \mathrm{L}$, progressively reducing the pharmacological options after every relapse.

There have been few clinical trials regarding the efficacy of treatment in patients co-infected with HIV, and the majority have been carried out in Europe (infections produced by $L$. infantum). There are still many unanswered questions as to which should be the drug of choice, and the dose, duration, maintenance therapy, prophylaxis and efficacy of combined therapies in co-infected patients (Table 4). 


\subsubsection{Oral Treatment}

3.3.1.1 Miltefosine Miltefosine has been used, but there is limited published clinical information about its efficacy, tolerability and safety in HIV patients. The optimal duration of treatment for primary infection or for relapsing cases has not been established. One of the few published reports took place in Europe, where miltefosine was used within the Compassionate Access Programme for those HIV patients in whom previous treatment for VL had failed. Although the initial cure rates were $64 \%$, almost all of the patients relapsed [103]. In Ethiopia, a randomized, non-blinded clinical trial was performed, comparing oral miltefosine $100 \mathrm{mg} /$ day for 28 days with sodium stibogluconate $20 \mathrm{mg} / \mathrm{kg} / \mathrm{day}$ for 30 days in a high-prevalence HIV population. The authors concluded that miltefosine was safer but less effective than sodium stibogluconate in HIV-infected patients [29]. Another publication has reported the use of miltefosine in the management of four co-infected patients in Spain. They were severely immunosuppressed patients whose previous treatment for VL with amphotericin B deoxycholate or meglumine antimoniate had failed. All of the patients seemed to respond with symptomatic improvement, but when treatment was discontinued, all of the patients relapsed [104].

\subsubsection{Parenteral Treatment}

3.3.2.1 Pentavalent Antimonials Although the prevalence of HIV-VL co-infection seems to be progressively increasing in India, with rates $>2-5 \%$ in some recent studies $[105,106]$, clear data on cure rates with antimonials in co-infected patients are not available. However, there are factors that could limit the use of antimonials for VL in HIV patients in India: firstly, the rate of resistance to pentavalent antimonials is high in India (especially in Bihar, observed in non HIV patients); and secondly, treatment regimens frequently need to be longer in HIV patients than in non-HIV patients, so this would probably increase the toxicity rates seen with antimonials.

Pentavalent antimonials have been used in co-infected patients at a dose of $20 \mathrm{mg} \mathrm{Sb}{ }^{\mathrm{v}+} / \mathrm{kg} / \mathrm{day}$ for 28-30 days in different European case series, with response rates between 33 and $82 \%$ and frequent relapses [107]. In two clinical European trials, which compared meglumine antimoniate with amphotericin B deoxycholate and liposomal amphotericin $\mathrm{B}$, the response rates recorded for antimonials were 65.9 and $37 \%[108,109]$.
In African data from Ethiopia, poor cure rates were also found, with only $43.5 \%$ of HIV-positive patients being cured at 6-month follow-up [110]. Better results were observed in another two studies performed in Ethiopian populations, with $65.2-78.6 \%$ cure rates, but a higher proportion of non-HIV-infected patients were included in the analysis [29, 42].

3.3.2.2 Pentamidine Regimens There have been no clinical trials with pentamidine, and experience is limited to clinical cases where, on many occasions, a combination with other drugs was used [111].

\subsubsection{Amphotericin B, Amphotericin B Lipid Complex} and Liposomal Amphotericin B Regimens Although amphotericin B deoxycholate is one of the first-line drugs in the treatment of VL, there has been only one comparative study in HIV-infected patients, which was carried out in Europe (Spain, L. infantum). This study demonstrated that at a dose of $0.7 \mathrm{mg} / \mathrm{kg} /$ day for 28 days $(20 \mathrm{mg} / \mathrm{kg}$ total dose), amphotericin B deoxycholate was equally as effective in the initial cure and prevention of relapses as antimonials (cure rate $62.6 \%$ ) [108].

A total dose of $30 \mathrm{mg} / \mathrm{kg}$ of amphotericin B lipid complex proved to be slightly superior to a total dose of $15 \mathrm{mg} / \mathrm{kg}$ amphotericin B lipid complex and to antimonials ( $20 \mathrm{mg} \mathrm{Sb}{ }^{\mathrm{v}+} / \mathrm{kg} /$ day for 28 days) in co-infected patients in a multicentre, open-label, blinded, randomized trial conducted in Europe (Spain. L. infantum). However, the response rate did not exceed $42 \%$ [109].

Two studies have been carried out with liposomal amphotericin B. One was in Ethiopia with a cohort of HIV-positive and -negative patients treated with liposomal amphotericin B (total dose $30 \mathrm{mg} / \mathrm{kg}$ ), with a cure rate of $60 \%$. Relapses were treated with sodium stibogluconate $(20 \mathrm{mg} / \mathrm{kg} /$ day for 30 days), increasing the final cure rate in co-infected patients to $83 \%$. However, $16 \%$ of these patients died as a direct result of the toxicity of sodium stibogluconate, highlighting the excess of toxicity in HIV-positive patients [112]. In India, another retrospective cohort study included recently diagnosed VLHIV co-infected patients starting liposomal amphotericin B treatment at total doses of $20-25 \mathrm{mg} / \mathrm{kg}$ over 4-15 days. Excellent tolerability was observed, and initially all patients responded to the treatment, with final cure rate of $85 \%$ after 1-2 years post-treatment. [113]. It is known that relapses can be treated in a similar way, as no resistance to amphotericin $\mathrm{B}$ deoxycholate has been noted. 


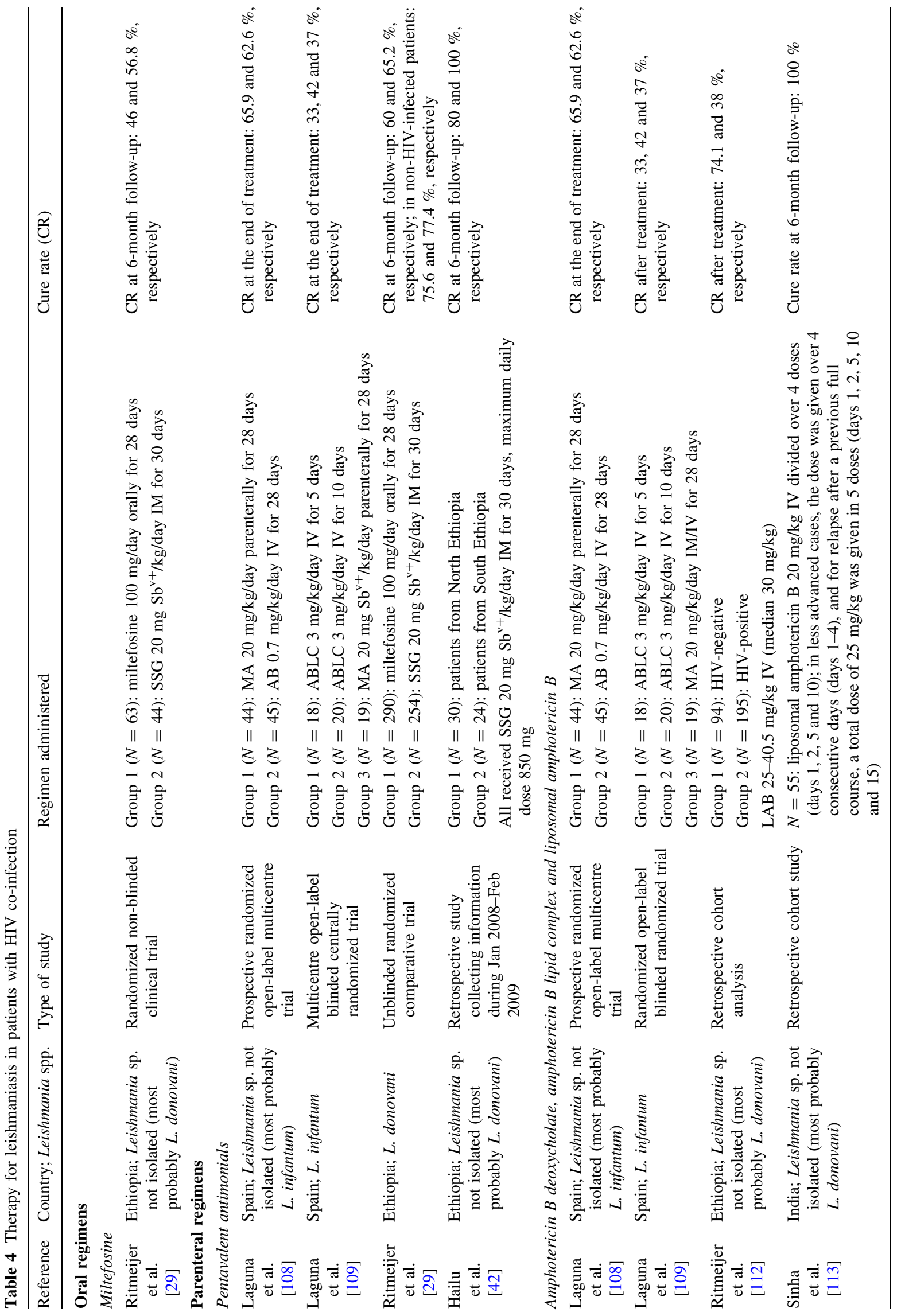




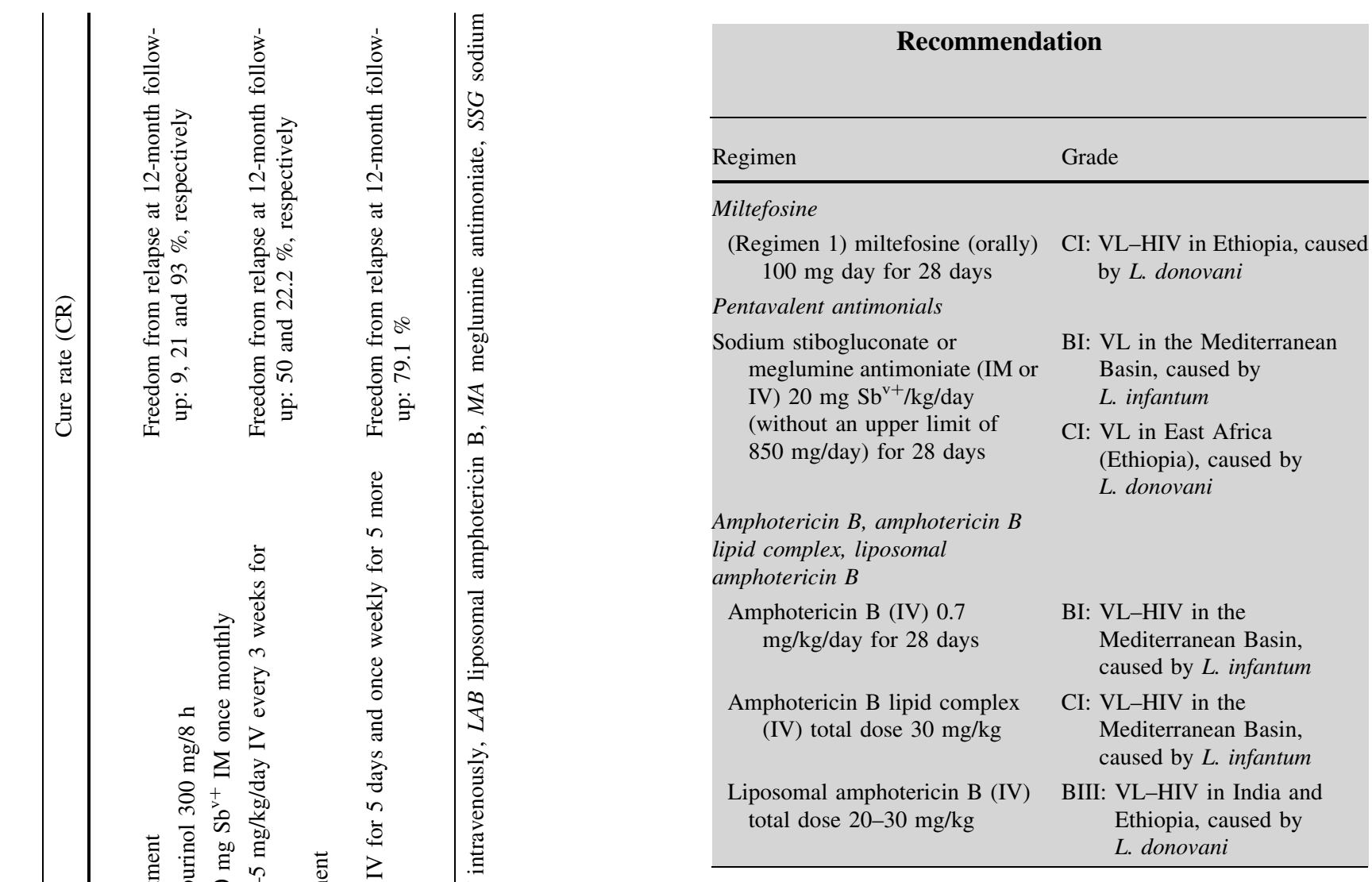

3.3.2.4 Paromomycin Regimens The efficacy of paromomycin has not been established, and it is considered to be a drug that fairly easily develops resistance [5]. The different trials that have proven its efficacy involved combined therapies with other drugs and were carried out mainly in HIV-negative patients.

3.3.2.5 Combination Therapy There are no data regarding the efficacy of combined therapy in HIV patients. Nonetheless, many experts are in favour of combined therapy for patients with multiple relapses [6]. Combinations of antimonials with other drugs such as allopurinol, ketoconazole, fluconazole, itraconazole or interferon- $\gamma$ have been used, but with insufficient evidence to consolidate the recommendation [114]. A case report from Italy described the safety and efficacy of the combination of liposomal amphotericin B (4 mg/kg/day for 5 consecutive days and on days 10, 14, 17, 31 and 38) and the growth factor recombinant human granulocyte/monocyte colony-stimulating factor (rHuGMCSF) $[150 \mu \mathrm{g}$ subcutaneously twice weekly for 12 consecutive weeks] in an HIV-positive patient with VL. No side effects were observed, and after 2 years of follow-up the patient was still free from disease [115].

3.3.2.6 Maintenance Therapy The data regarding maintenance therapy after a treated episode of VL in 
HIV-infected patients has fundamentally been developed in Europe, where zoonotic transmission occurs by L. infantum.

The only randomized clinical trial, which took place in Spain, reported that use of amphotericin B lipid complex as maintenance therapy administered at a dose of $3-5 \mathrm{mg} / \mathrm{kg} /$ day IV every 3 weeks for 12 months, versus no treatment at all, lowered the relapse rate from 50 to $22 \%$ [116]. Another prospective study, also carried out in Spain, analyzed the efficacy of maintenance therapy with liposomal amphotericin B at $4 \mathrm{mg} / \mathrm{kg} / \mathrm{day}$ for 5 days and once weekly for 5 more weeks (total 10 doses), achieving up to $80 \%$ patients being free of disease after 12 months of follow-up [117].

Pentavalent antimonials were administered every 3-4 weeks as maintenance therapy in a study conducted in Spain. The rate of relapses reduced much more significantly than in those patients who either did not receive any treatment or who took allopurinol for the 12 months of follow-up [118].

Pentamidine was used at a dose of $4 \mathrm{mg} / \mathrm{kg} /$ day every 2-4 weeks in HIV-positive patients with VL caused by L. infantum, without any evidence of relapses during the follow-up period [119, 120].

Five cases reported in a study performed in Portugal observed that the three patients who received miltefosine as secondary prophylaxis for 21,14 and 12 months, respectively, remained disease free for a median period of 20 months. Miltefosine could be a good option for maintenance therapy until improvement of immune function (CD4+ cell count $>250 / \mathrm{mm}^{3}$ ), because of its long half-life and ease of oral administration. This could allow ambulatory treatment and even dose reductions, using an alternateday regimen [121].

Azole drugs could be effective in maintenance therapy, although there are no clinical trials to support this theory. The experience is based on series of cases where itraconazole was given at a dose of $600 \mathrm{mg} /$ day for up to 24 months of treatment, without any relapses. The advantage of these drugs is their good tolerability and low toxicity, although there is a risk of developing resistant fungal infections [122, 123]. Itraconazole or fluconazole combined with allopurinol could be an option $[124,10]$.

Another relevant aspect to take into account is how long maintenance therapy should be continued. According to different authors, once the patient has recovered their immune function with highly active antiretroviral therapy (HAART) and the VL is quiescent, suspension of prophylaxis could then be considered when the CD4+ count has been maintained at $>200$ cells $/ \mu \mathrm{L}$ for more than 6 months $[125,126]$.

\section{Recommendation*}

\begin{tabular}{|c|c|}
\hline Maintenance regimen & Grade \\
\hline $\begin{array}{l}\text { (Regimen 1) amphotericin B lipid } \\
\text { complex (IV) } 3-5 \mathrm{mg} / \mathrm{kg} / \text { day } \\
\text { every } 3 \text { weeks }\end{array}$ & $\begin{array}{l}\text { AI: (regimen } 1 \text { ): VL in the } \\
\text { Mediterranean Basin, } \\
\text { caused by } L \text {. infantum }\end{array}$ \\
\hline $\begin{array}{l}\text { (Regimen 2) meglumine } \\
\text { antimoniate (IM or IV) } 850 \mathrm{mg} \\
\mathrm{Sb}^{\mathrm{v}+} \text { in adults every } 4 \text { weeks }\end{array}$ & $\begin{array}{l}\text { AII: (regimen 2): VL in the } \\
\text { Mediterranean Basin, } \\
\text { caused by } L \text {. infantum }\end{array}$ \\
\hline $\begin{array}{l}\text { (Regimen } 3 \text { ) pentamidine } \\
\text { isethionate (IV) } 4 \mathrm{mg} / \mathrm{kg} / \mathrm{day} \\
\text { every } 2-4 \text { weeks }\end{array}$ & $\begin{array}{l}\text { CIII: (regimen } 3 \text { ): VL in the } \\
\text { Mediterranean Basin, } \\
\text { caused by } L \text {. infantum }\end{array}$ \\
\hline
\end{tabular}

*Suspension of maintenance therapy could be considered after HAART when the patient is stable and the CD4+ has been maintained at $>200$ cells $/ \mu \mathrm{L}$ for $>6$ months

\section{Conclusions}

Currently, the control of VL relies primarily on chemotherapy. The traditional treatment for VL used to be pentavalent antimonials, introduced in the late 1940s. However, the development of resistance, especially in India, with failure rates of up to $60 \%$, as well as their potential toxicity, made it necessary to seek new treatment options. Thus, since the 1980s, the use of amphotericin B deoxycholate has been introduced, especially in more developed countries. Progressively, and because of their efficacy and lower toxicity, lipid formulations of amphotericin have been gaining importance, becoming the firstchoice treatment established by the US Food and Drug Administration (FDA). However, their elevated cost has somewhat limited their use, but since the introduction of the recent Gilead/WHO AmBisome donation programme to Bangladesh, Nepal, Sudan, South Sudan, Ethiopia and Kenya, this situation has improved. Several studies have demonstrated the efficacy of paromomycin as a cheap parenteral treatment with medium toxicity. Within the range of oral treatments, miltefosine has been fundamentally used on the Indian subcontinent. Combination therapy will ultimately became the best drug regimen for treating VL in many parts of the world.

Treatment of VL in HIV co-infected patients is less effective than in HIV-negative patients, and relapses are much more frequent. Within the available treatment options, amphotericin B deoxycholate and particularly lipid formulations seem to be the most effective. Meanwhile, it seems that standard treatment with antimonials should be avoided because of their high toxicity in HIVpositive patients. Another difficulty that is hard to manage in co-infected patients is the frequent relapses. There is 
very little evidence regarding which drugs, doses and durations to use for maintenance therapy. The common relapses and prolonged secondary prophylaxis regimens could favour the development of resistant strains, which limit therapeutic options even further and create an epidemiological issue in areas of anthroponotic VL transmission.

Acknowledgements We thank Christine Klein for the English translation and the technical assistance.

Support was provided by the Red de Investigación de Centros de Enfermedades Tropicales (RED: RD06/0021/0020).

Open Access This article is distributed under the terms of the Creative Commons Attribution Noncommercial License which permits any noncommercial use, distribution, and reproduction in any medium, provided the original author(s) and the source are credited.

\section{References}

1. van Griensven J, Diro E. Visceral leishmaniasis. Infect Dis Clin North Am. 2012;26:309-22.

2. Alvar J, Velez ID, Bern C, et al. Leishmaniasis worldwide and global estimates of its incidence. PLoS One. 2012;7:e35671.

3. Sundar S, Chakravarty J. Leishmaniasis: an update of current pharmacotherapy. Expert Opin Pharmacother. 2013;14:53-63.

4. Alvar J, Croft S, Olliaro P. Chemotherapy in the treatment and control of leishmaniasis. Adv Parasitol. 2006;61:223-74.

5. Croft SL, Sundar S, Fairlamb AH. Drug resistance in leishmaniasis. Clin Microbiol Rev. 2006;19:111-26.

6. Alvar J, Aparicio P, Aseffa A, et al. The relationship between leishmaniasis and AIDS: the second 10 years. Clin Microbiol Rev. 2008;21:334-59.

7. World Health Organization. WHO technical report series. Control of the leishmaniases. Report of a meeting of the WHO expert committee on the control of leishmaniases, Geneva, 2010. http://whqlibdoc.who.int/trs/WHO_TRS_949_eng.pdf.

8. Khan AR, Khan S, Zimmerman V, Baddour LM, Tleyjeh IM. Quality and strength of evidence of the Infectious Diseases Society of America clinical practice guidelines. Clin Infect Dis. 2010;51:1147-56.

9. Kish MA. Infectious Diseases Society of America. Guide to development of practice guidelines. Clin Infect Dis. 2001;32: $851-4$.

10. Torrus D, Boix V, Massa B, Portilla J, Perez-Mateo M. Fluconazole plus allopurinol in treatment of visceral leishmaniasis. J Antimicrob Chemother. 1996;37:1042-3.

11. Kager PA, Rees PH, Wellde BT, Hockmeyer WT, Lyerly WH. Allopurinol in the treatment of visceral leishmaniasis. Trans $\mathrm{R}$ Soc Trop Med Hyg. 1981;75:556-9.

12. Ragusa R, Di Cataldo A, Samperi P, Schiliro G. Treatment of visceral leishmaniasis with meglumine and allopurinol. Am J Dis Child. 1993;147:611-2.

13. Sundar S, Kumar K, Singh VP. Ketoconazole in visceral leishmaniasis. Lancet. 1990;336:1582-3.

14. Wali JP, Aggarwal P, Gupta U, Saluja S, Singh S. Ketoconazole in the treatment of antimony- and pentamidine-resistant kalaazar. J Infect Dis. 1992;166:215-6.

15. Halim MA, Alfurayh O, Kalin ME, Dammas S, al-Eisa A, Damanhouri G. Successful treatment of visceral leishmaniasis with allopurinol plus ketoconazole in a renal transplant recipient after the occurrence of pancreatitis due to stibogluconate. Clin Infect Dis. 1993;16:397-9.

16. Hueso M, Bover J, Seron D, et al. The renal transplant patient with visceral leishmaniasis who could not tolerate meglumine antimoniate-cure with ketoconazole and allopurinol. Nephrol Dial Transpl. 1999;14:2941-3.

17. Sundar S, Jha TK, Thakur CP, Bhattacharya SK, Rai M. Oral miltefosine for the treatment of Indian visceral leishmaniasis. Trans R Soc Trop Med Hyg. 2006;100(Suppl 1):S26-33.

18. Sundar S, Gupta LB, Makharia MK, et al. Oral treatment of visceral leishmaniasis with miltefosine. Ann Trop Med Parasitol. 1999;93:589-97.

19. Sundar S, Makharia A, More DK, et al. Short-course of oral miltefosine for treatment of visceral leishmaniasis. Clin Infect Dis. 2000;31:1110-3.

20. Sundar S, Jha TK, Sindermann H, Junge K, Bachmann P, Berman J. Oral miltefosine treatment in children with mild to moderate Indian visceral leishmaniasis. Pediatr Infect Dis J. 2003;22:434-8.

21. Bhattacharya SK, Jha TK, Sundar S, et al. Efficacy and tolerability of miltefosine for childhood visceral leishmaniasis in India. Clin Infect Dis. 2004;38:217-21.

22. Singh UK, Prasad R, Mishra OP, Jayswal BP. Miltefosine in children with visceral leishmaniasis: a prospective, multicentric, cross-sectional study. Indian J Pediatr. 2006;73:1077-80.

23. Rahman M, Ahmed BN, Faiz MA, et al. Phase IV trial of miltefosine in adults and children for treatment of visceral leishmaniasis (kala-azar) in Bangladesh. Am J Trop Med Hyg. 2011;85:66-9.

24. Sundar S, Singh A, Rai M, et al. Efficacy of miltefosine in the treatment of visceral leishmaniasis in India after a decade of use. Clin Infect Dis. 2012;55:543-50.

25. Perez-Victoria FJ, Castanys S, Gamarro F. Leishmania donovani resistance to miltefosine involves a defective inward translocation of the drug. Antimicrob Agents Chemother. 2003;47: 2397-403.

26. Perez-Victoria FJ, Sanchez-Canete MP, Seifert K, et al. Mechanisms of experimental resistance of Leishmania to miltefosine: implications for clinical use. Drug Resist Updat. 2006;9:26-39.

27. Rijal S, Ostyn B, Uranw S, et al. Increasing failure of miltefosine in the treatment of kala-azar in Nepal and the potential role of parasite drug resistance, reinfection, or noncompliance. Clin Infect Dis. 2013;56:1530-8.

28. Prajapati VK, Sharma S, Rai M, et al. In vitro susceptibility of Leishmania donovani to miltefosine in indian visceral leishmaniasis. Am J Trop Med Hyg. 2013;89:750-4.

29. Ritmeijer K, Dejenie A, Assefa Y, et al. A comparison of miltefosine and sodium stibogluconate for treatment of visceral leishmaniasis in an Ethiopian population with high prevalence of HIV infection. Clin Infect Dis. 2006;43:357-64.

30. Sundar S, Rai M. Advances in the treatment of leishmaniasis. Curr Opin Infect Dis. 2002;15:593-8.

31. Bryceson AD. Therapy in man. In: Peters W, Killick-Kendrich $\mathrm{R}$, editors. The leishmaniasis in biology and medicine. London: Academics Press; 1987. p. 848-903.

32. Anabwani GM, Ngira JA, Dimiti G, Bryceson AD. Comparison of two dosage schedules of sodium stibogluconate in the treatment of visceral leishmaniasis in Kenya. Lancet. 1983;1:210-3.

33. Thakur CP, Kumar M, Pandey AK. Evaluation of efficacy of longer durations of therapy of fresh cases of kala-azar with sodium stibogluconate. Indian J Med Res. 1991;93:103-10.

34. World Health Organization. Report of the informal meeting on the chemotherapy of visceral leishmaniasis, WHO. Geneva, 1982.

35. Thakur CP, Kumar M, Kumar P, Mishra BN, Pandey AK. Rationalisation of regimens of treatment of kala-azar with 
sodium stibogluconate in India: a randomised study. Br Med J (Clin Res Ed). 1988;296:1557-61.

36. Thakur CP, Narayan S. A comparative evaluation of amphotericin B and sodium antimony gluconate, as first-line drugs in the treatment of Indian visceral leishmaniasis. Ann Trop Med Parasitol. 2004;98:129-38.

37. Herwaldt BL, Berman JD. Recommendations for treating leishmaniasis with sodium stibogluconate (pentostam) and review of pertinent clinical studies. Am J Trop Med Hyg. 1992;46:296-306

38. Seaman J, Pryce D, Sondorp HE, Moody A, Bryceson AD, Davidson RN. Epidemic visceral leishmaniasis in Sudan: a randomized trial of aminosidine plus sodium stibogluconate versus sodium stibogluconate alone. J Infect Dis. 1993;168: $715-20$.

39. Veeken H, Ritmeijer K, Seaman J, Davidson R. A randomized comparison of branded sodium stibogluconate and generic sodium stibogluconate for the treatment of visceral leishmaniasis under field conditions in Sudan. Trop Med Int Health. 2000;5:312-7.

40. Moore E, O'Flaherty D, Heuvelmans H, et al. Comparison of generic and proprietary sodium stibogluconate for the treatment of visceral leishmaniasis in Kenya. Bull World Health Organ. 2001;79:388-93.

41. Mueller Y, Nguimfack A, Cavailler P, et al. Safety and effectiveness of amphotericin B deoxycholate for the treatment of visceral leishmaniasis in Uganda. Ann Trop Med Parasitol. 2008;102:11-9.

42. Hailu W, Weldegebreal T, Hurissa Z, et al. Safety and effectiveness of meglumine antimoniate in the treatment of Ethiopian visceral leishmaniasis patients with and without HIV co-infection. Trans R Soc Trop Med Hyg. 2010;104:706-12.

43. Gradoni L, Soteriadou K, Louzir H, et al. Drug regimens for visceral leishmaniasis in mediterranean countries. Trop Med Int Health. 2008;13:1272-6.

44. Gradoni L, Bryceson A, Desjeux P. Treatment of Mediterranean visceral leishmaniasis. Bull World Health Organ. 1995;73: 191-7.

45. Petrela R, Kuneshka L, Foto E, Zavalani F, Gradoni L. Pediatric visceral leishmaniasis in Albania: a retrospective analysis of 1,210 consecutive hospitalized patients (1995-2009). PLoS Negl Trop Dis. 2010;4:e814.

46. Jeronimo SM, Duggal P, Braz RF, et al. An emerging peri-urban pattern of infection with Leishmania chagasi, the protozoan causing visceral leishmaniasis in northeast Brazil. Scand J Infect Dis. 2004;36:443-9.

47. Santos MA, Marques RC, Farias CA, et al. Predictors of an unsatisfactory response to pentavalent antimony in the treatment of American visceral leishmaniasis. Rev Soc Bras Med Trop. 2002;35:629-33.

48. Organización Panamericana de la Salud. Leishmaniasis en las Americas. Recomedaciones para el tratamiento. Washington, DC OPS, 2013. http://www.paho.org/hq/index.php?option= com_docman\&task=doc_view\&gid=22226\&Itemid=.

49. Sampaio SA, Godoy JT, Paiva L, Dillon NL, da Lacaz CS. The treatment of American (mucocutaneous) leishmaniasis with amphotericin B. Arch Dermatol. 1960;82:627-35.

50. Prata A. Treatment of kala-azar with amphotericin B. Trans R Soc Trop Med Hyg. 1963;57:266-8.

51. Jha TK, Giri YN, Singh TK, Jha S. Use of amphotericin B in drug-resistant cases of visceral leishmaniasis in North Bihar, India. Am J Trop Med Hyg. 1995;52:536-8.

52. Thakur CP, Sinha GP, Pandey AK, Barat D, Sinha PK. Amphotericin B in resistant kala-azar in Bihar. Natl Med J India. 1993;6:57-60.
53. Singh UK, Prasad R, Jaiswal BP, Singh PK, Thakur CP. Amphotericin B therapy in children with visceral leishmaniasis: daily vs. alternate day, a randomized trial. J Trop Pediatr. 2010;56:321-4

54. Thakur CP, Ahmed S. Observations on amphotericin B treatment of kala-azar given in a rural set up in Bihar, India. Indian $\mathrm{J}$ Med Res. 2001;113:14-8.

55. Mishra M, Biswas UK, Jha AM, Khan AB. Amphotericin versus sodium stibogluconate in first-line treatment of Indian kala-azar. Lancet. 1994;344:1599-600.

56. Thakur CP, Sinha GP, Pandey AK, Barat D, Singh RK. Daily versus alternate-day regimen of amphotericin $\mathrm{B}$ in the treatment of kala-azar: a randomized comparison. Bull World Health Organ. 1994;72:931-6.

57. Toumi A, Kilani B, Ammari L, et al. Demographic, clinical and therapeutic features of adult visceral leishmaniasis at the Rabta Hospital in Tunis (Tunisia) from 1983 to 2002. Bull Soc Pathol Exot. 2007;100:282-6.

58. Sundar S, Mehta H, Suresh AV, Singh SP, Rai M, Murray HW. Amphotericin B treatment for Indian visceral leishmaniasis: conventional versus lipid formulations. Clin Infect Dis. 2004;38: 377-83.

59. Thakur CP. A single high dose treatment of kala-azar with ambisome (amphotericin B lipid complex): a pilot study. Int J Antimicrob Agents. 2001;17:67-70.

60. Sundar S, Jha TK, Thakur CP, Mishra M, Singh VR, Buffels R. Low-dose liposomal amphotericin B in refractory Indian visceral leishmaniasis: a multicenter study. Am J Trop Med Hyg. 2002;66:143-6.

61. Sinha PK, Roddy P, Palma PP, et al. Effectiveness and safety of liposomal amphotericin $\mathrm{B}$ for visceral leishmaniasis under routine program conditions in Bihar, India. Am J Trop Med Hyg. 2010;83:357-64.

62. Thakur CP, Pandey AK, Sinha GP, Roy S, Behbehani K, Olliaro $\mathrm{P}$. Comparison of three treatment regimens with liposomal amphotericin B (AmBisome) for visceral leishmaniasis in India: a randomized dose-finding study. Trans R Soc Trop Med Hyg. 1996;90:319-22.

63. Sundar S, Agrawal G, Rai M, Makharia MK, Murray HW. Treatment of Indian visceral leishmaniasis with single or daily infusions of low dose liposomal amphotericin B: randomised trial. BMJ. 2001;323:419-22.

64. Sundar S, Jha TK, Thakur CP, Mishra M, Singh VP, Buffels R. Single-dose liposomal amphotericin B in the treatment of visceral leishmaniasis in India: a multicenter study. Clin Infect Dis. 2003;37:800-4.

65. Sundar S, Chakravarty J, Agarwal D, Rai M, Murray HW. Single-dose liposomal amphotericin B for visceral leishmaniasis in India. N Engl J Med. 2010;362:504-12.

66. Seaman J, Boer C, Wilkinson R, et al. Liposomal amphotericin B (AmBisome) in the treatment of complicated kala-azar under field conditions. Clin Infect Dis. 1995;21:188-93.

67. Mueller M, Ritmeijer K, Balasegaram M, Koummuki Y, Santana MR, Davidson R. Unresponsiveness to AmBisome in some Sudanese patients with kala-azar. Trans R Soc Trop Med Hyg. 2007;101:19-24.

68. Berman JD, Badaro R, Thakur CP, et al. Efficacy and safety of liposomal amphotericin B (AmBisome) for visceral leishmaniasis in endemic developing countries. Bull World Health Organ. 1998; 76:25-32.

69. Lagler H, Matt U, Sillaber C, Winkler S, Graninger W. Successful treatment of visceral leishmaniasis with liposomal amphotericin B. Acta Biomed. 2006;77(Suppl 2):22-5.

70. Edwards T, Omollo R, Khalil EA, et al. Single-dose liposomal amphotericin B (AmBisome ${ }^{\circledR}$ ) for the treatment of visceral 
leishmaniasis in East Africa: study protocol for a randomized controlled trial. Trials. 2011;12:66.

71. Davidson RN, Di Martino L, Gradoni L, et al. Liposomal amphotericin B (AmBisome) in Mediterranean visceral leishmaniasis: a multi-centre trial. Q J Med. 1994;87:75-81.

72. Davidson RN, di Martino L, Gradoni L, et al. Short-course treatment of visceral leishmaniasis with liposomal amphotericin B (AmBisome). Clin Infect Dis. 1996;22:938-43.

73. Syriopoulou V, Daikos GL, Theodoridou M, et al. Two doses of a lipid formulation of amphotericin B for the treatment of Mediterranean visceral leishmaniasis. Clin Infect Dis. 2003;36: $560-6$.

74. Figueras Nadal MC, de Garcia Miguel MJ, Asensi Botet F, Velasco Bernardo R, Canals Baeza A, Ausin Aoiz I. Short course treatment for visceral leishmaniasis with liposomal amphotericin B in immunocompetent patients. An Pediatr (Barc). 2003;59:535-40.

75. Minodier P, Robert S, Noel G, Blanc P, Retornaz K, Garnier JM. First-line liposomal amphotericin B for pediatric visceral leishmaniasis in Southern France. Arch Pediatr. 2005;12: 1102-8.

76. Kafetzis DA, Velissariou IM, Stabouli S, Mavrikou M, Delis D, Liapi G. Treatment of paediatric visceral leishmaniasis: amphotericin B or pentavalent antimony compounds? Int $\mathrm{J}$ Antimicrob Agents. 2005;25:26-30.

77. Minodier P, Garnier JM. Childhood visceral leishmaniasis in Provence. Arch Pediatr. 2000;7(Suppl 3):572s-7s.

78. Rosenthal E, Delaunay P, Jeandel PY, Haas H, Pomares-Estran C, Marty P. Liposomal amphotericin B as treatment for visceral leishmaniasis in Europe, 2009. Med Mal Infect. 2009;39:741-4.

79. Velez ID, Colmenares LM, Munoz CA. Two cases of visceral leishmaniasis in Colombia resistant to meglumine antimonial treatment. Rev Inst Med Trop Sao Paulo. 2009;51:231-6.

80. Sundar S, Chakravarty J, Agarwal D, Shah A, Agrawal N, Rai M. Safety of a pre-formulated amphotericin B lipid emulsion for the treatment of Indian kala-azar. Trop Med Int Health. 2008;13:1208-12.

81. Sundar S, Singh A, Agarwal D, Rai M, Agrawal N, Chakravarty J. Safety and efficacy of high-dose infusions of a preformed amphotericin B fat emulsion for treatment of Indian visceral leishmaniasis. Am J Trop Med Hyg. 2009;80:700-3.

82. Thakur CP. Epidemiological, clinical and therapeutic features of Bihar kala-azar (including post kala-azar dermal leishmaniasis). Trans R Soc Trop Med Hyg. 1984;78:391-8.

83. Mishra M, Biswas UK, Jha DN, Khan AB. Amphotericin versus pentamidine in antimony-unresponsive kala-azar. Lancet. 1992;340:1256-7.

84. Das VN, Siddiqui NA, Pandey K, et al. A controlled, randomized nonblinded clinical trial to assess the efficacy of amphotericin B deoxycholate as compared to pentamidine for the treatment of antimony unresponsive visceral leishmaniasis cases in Bihar, India. Ther Clin Risk Manag. 2009;5:117-24.

85. Das VN, Ranjan A, Sinha AN, et al. A randomized clinical trial of low dosage combination of pentamidine and allopurinol in the treatment of antimony unresponsive cases of visceral leishmaniasis. J Assoc Phys India. 2001;49:609-13.

86. Thakur CP, Kumar M, Pandey AK. Comparison of regimes of treatment of antimony-resistant kala-azar patients: a randomized study. Am J Trop Med Hyg. 1991;45:435-41.

87. Khalil EA, el Hassan AM, Zijlstra EE, et al. Treatment of visceral leishmaniasis with sodium stibogluconate in Sudan: management of those who do not respond. Ann Trop Med Parasitol. 1998;92:151-8.

88. Jha TK, Olliaro $\mathrm{P}$, Thakur CP, et al. Randomised controlled trial of aminosidine (paromomycin) $\mathrm{v}$ sodium stibogluconate for treating visceral leishmaniasis in north Bihar, India. BMJ. 1998;316:1200-5.

89. Sundar S, Jha TK, Thakur CP, Sinha PK, Bhattacharya SK. Injectable paromomycin for visceral leishmaniasis in India. N Engl J Med. 2007;356:2571-81.

90. Sundar S, Agrawal N, Arora R, Agarwal D, Rai M, Chakravarty J. Short-course paromomycin treatment of visceral leishmaniasis in India: 14-day vs 21-day treatment. Clin Infect Dis. 2009;49:914-8.

91. Sinha PK, Jha TK, Thakur CP, et al. Phase 4 pharmacovigilance trial of paromomycin injection for the treatment of visceral leishmaniasis in India. J Trop Med. 2011;2011:645203.

92. Chunge CN, Owate J, Pamba HO, Donno L. Treatment of visceral leishmaniasis in Kenya by aminosidine alone or combined with sodium stibogluconate. Trans R Soc Trop Med Hyg. 1990;84:221-5.

93. Melaku Y, Collin SM, Keus K, Gatluak F, Ritmeijer K, Davidson RN. Treatment of kala-azar in Southern Sudan using a 17-day regimen of sodium stibogluconate combined with paromomycin: a retrospective comparison with 30-day sodium stibogluconate monotherapy. Am J Trop Med Hyg. 2007;77: 89-94.

94. Hailu A, Musa A, Wasunna M, et al. Geographical variation in the response of visceral leishmaniasis to paromomycin in east Africa: a multicentre, open-label, randomized trial. PLoS Negl Trop Dis. 2010;4:e709.

95. Musa AM, Younis B, Fadlalla A, et al. Paromomycin for the treatment of visceral leishmaniasis in Sudan: a randomized, open-label, dose-finding study. PLoS Negl Trop Dis. 2010;4: e855.

96. Thakur CP, Kanyok TP, Pandey AK, et al. A prospective randomized, comparative, open-label trial of the safety and efficacy of paromomycin (aminosidine) plus sodium stibogluconate versus sodium stibogluconate alone for the treatment of visceral leishmaniasis. Trans R Soc Trop Med Hyg. 2000;94:429-31.

97. Thakur CP, Olliaro P, Gothoskar S, et al. Treatment of visceral leishmaniasis (kala-azar) with aminosidine (= paromomycin)antimonial combinations, a pilot study in Bihar, India. Trans R Soc Trop Med Hyg. 1992;86:615-6.

98. Sundar S, Rai M, Chakravarty J, et al. New treatment approach in Indian visceral leishmaniasis: single-dose liposomal amphotericin B followed by short-course oral miltefosine. Clin Infect Dis. 2008;47:1000-6.

99. Sundar S, Sinha PK, Rai M, et al. Comparison of short-course multidrug treatment with standard therapy for visceral leishmaniasis in India: an open-label, non-inferiority, randomised controlled trial. Lancet. 2011;377:477-86.

100. Sundar S, Sinha PK, Verma DK, et al. Ambisome plus miltefosine for Indian patients with kala-azar. Trans R Soc Trop Med Hyg. 2011;105:115-7.

101. Musa A, Khalil E, Hailu A, et al. Sodium stibogluconate (SSG) \& paromomycin combination compared to SSG for visceral leishmaniasis in east Africa: a randomised controlled trial. PLoS Negl Trop Dis. 2012;6:e1674.

102. Omollo R, Alexander N, Edwards T, et al. Safety and efficacy of miltefosine alone and in combination with sodium stibogluconate and liposomal amphotericin B for the treatment of primary visceral leishmaniasis in East Africa: study protocol for a randomized controlled trial. Trials. 2011;12:166.

103. Sindermann H, Engel KR, Fischer C, Bommer W, Miltefosine Compassionate Use Program. Oral miltefosine for leishmaniasis in immunocompromised patients: compassionate use in 39 patients with HIV infection. Clin Infect Dis. 2004;39:1520-3.

104. Troya J, Casquero A, Refoyo E, Fernandez-Guerrero ML, Gorgolas M. Long term failure of miltefosine in the treatment of 
refractory visceral leishmaniasis in AIDS patients. Scand J Infect Dis. 2008;40:78-80.

105. Redhu NS, Dey A, Balooni V, Singh S. Leishmania-HIV co-infection: an emerging problem in India. AIDS. 2006;20: 1213-5.

106. Sinha PK, Rabidas VN, Pandey K, et al. Visceral leishmaniasis and HIV co-infection in Bihar, India. J Acquir Immune Defic Syndr. 2003;32:115-6.

107. Pintado V, Lopez-Velez R. HIV-associated visceral leishmaniasis. Clin Microbiol Infect. 2001;7:291-300.

108. Laguna F, Lopez-Velez R, Pulido F, et al. Treatment of visceral leishmaniasis in HIV-infected patients: a randomized trial comparing meglumine antimoniate with amphotericin B. Spanish HIV-Leishmania Study Group. AIDS. 1999;13:1063-9.

109. Laguna F, Videla S, Jimenez-Mejias ME, et al. Amphotericin B lipid complex versus meglumine antimoniate in the treatment of visceral leishmaniasis in patients infected with HIV: a randomized pilot study. J Antimicrob Chemother. 2003;52:464-8.

110. Ritmeijer K, Veeken H, Melaku Y, et al. Ethiopian visceral leishmaniasis: generic and proprietary sodium stibogluconate are equivalent; HIV co-infected patients have a poor outcome. Trans R Soc Trop Med Hyg. 2001;95:668-72.

111. Rybniker J, Goede V, Mertens J, et al. Treatment of visceral leishmaniasis with intravenous pentamidine and oral fluconazole in an HIV-positive patient with chronic renal failure-a case report and brief review of the literature. Int $\mathrm{J}$ Infect Dis. 2010;14:e522-5.

112. Ritmeijer K, ter Horst R, Chane S, et al. Limited effectiveness of high-dose liposomal amphotericin B (AmBisome) for treatment of visceral leishmaniasis in an Ethiopian population with high HIV prevalence. Clin Infect Dis. 2011;53:e152-8.

113. Sinha PK, van Griensven J, Pandey K, et al. Liposomal amphotericin B for visceral leishmaniasis in human immunodeficiency virus-coinfected patients: 2-year treatment outcomes in Bihar, India. Clin Infect Dis. 2011;53:e91-8.

114. Laguna F, Lopez-Velez R, Soriano V, Montilla P, Alvar J, Gonzalez-Lahoz JM. Assessment of allopurinol plus meglumine antimoniate in the treatment of visceral leishmaniasis in patients infected with HIV. J Infect. 1994;28:255-9.

115. Mastroianni A. Liposomal amphotericin B and rHuGM-CSF for treatment of visceral leishmaniasis in AIDS. Infez Med. 2004; 12:197-204.

116. Lopez-Velez R, Videla S, Marquez M, et al. Amphotericin B lipid complex versus no treatment in the secondary prophylaxis of visceral leishmaniasis in HIV-infected patients. J Antimicrob Chemother. 2004;53:540-3.

117. Molina I, Falco V, Crespo M, et al. Efficacy of liposomal amphotericin B for secondary prophylaxis of visceral leishmaniasis in HIV-infected patients. J Antimicrob Chemother. 2007;60:837-42.

118. Ribera E, Ocana I, de Otero J, Cortes E, Gasser I, Pahissa A. Prophylaxis of visceral leishmaniasis in human immunodeficiency virus-infected patients. Am J Med. 1996;100:496-501.

119. Lopez-Velez R, Perez-Molina JA, Guerrero A, et al. Clinicoepidemiologic characteristics, prognostic factors, and survival analysis of patients co-infected with human immunodeficiency virus and Leishmania in an area of Madrid, Spain. Am J Trop Med Hyg. 1998;58:436-43.

120. Perez-Molina JA, Lopez-Velez R, Montilla P, Guerrero A. Pentamidine isethionate as secondary prophylaxis against visceral leishmaniasis in HIV-positive patients. AIDS. 1996;10: 237-8.
121. Marques N, Sa R, Coelho F, Oliveira J, Saraiva Da Cunha J, Melico-Silvestre A. Miltefosine for visceral leishmaniasis relapse treatment and secondary prophylaxis in HIV-infected patients. Scand J Infect Dis. 2008;40:523-6.

122. Angarano G, Maggi P, Coppola SL, Cavaliere RL. Itraconazole as maintenance therapy for visceral leishmaniasis in HIVinfected patients. Eur J Clin Microbiol Infect Dis. 1998;17: $365-7$.

123. Lafeuillade A, Chaffanjon P, Delbeke E, Quilichini R. Maintenance itraconazole for visceral leishmaniasis in HIV infection. Am J Med. 1992;92:449.

124. Raffi F, Merrien D, Le Pape P, Reliquet V. Use of an Itraconazole/allopurinol combination for the treatment of visceral leishmaniasis in a patient with AIDS. Clin Infect Dis. 1995;21: 1338-9.

125. Berenguer J, Cosin J, Miralles P, Lopez JC, Padilla B. Discontinuation of secondary anti-Leishmania prophylaxis in HIV-infected patients who have responded to highly active antiretroviral therapy. AIDS. 2000;14:2946-8.

126. Soriano VF, Dona CF, Rodriguez-Rosado RF, Barreiro PF, Gonzalez-Lahoz J. Discontinuation of secondary prophylaxis for opportunistic infections in HIV-infected patients receiving highly active antiretroviral therapy. AIDS. 2000;14:383-6.

127. Sundar S, Rosenkaimer F, Makharia MK, et al. Trial of oral miltefosine for visceral leishmaniasis. Lancet. 1998;352:1821-3.

128. Jha TK, Sundar S, Thakur CP, et al. Miltefosine, an oral agent, for the treatment of Indian visceral leishmaniasis. N Engl J Med. 1999;341:1795-800.

129. Sundar S, Jha TK, Thakur CP, et al. Oral miltefosine for Indian visceral leishmaniasis. N Engl J Med. 2002;347:1739-46.

130. Bhattacharya SK, Sinha PK, Sundar S, et al. Phase 4 trial of miltefosine for the treatment of Indian visceral leishmaniasis. J Infect Dis. 2007;196:591-8.

131. Mishra M, Singh MP, Choudhury D, Singh VP, Khan AB. Amphotericin B for second-line treatment of Indian kala-azar. Lancet. 1991;337:926.

132. Thakur CP, Sinha GP, Sharma V, Pandey AK, Kumar M, Verma BB. Evaluation of amphotericin B as a first line drug in comparison to sodium stibogluconate in the treatment of fresh cases of kala-azar. Indian J Med Res. 1993;97:170-5.

133. Thakur CP, Sinha GP, Barat D, Singh RK. Are incremental doses of amphotericin B required for the treatment of visceral leishmaniasis? Ann Trop Med Parasitol. 1994;88:365-70.

134. Giri OP. Treatment of visceral leishmaniasis unresponsive to pentamidine with amphotericin B. J Assoc Phys India. 1994;42: 688-9.

135. Giri OP, Singh AN. Experience with amphotericin B in sodium stibogluconate-unresponsive cases of visceral leishmaniasis in North Bihar. J Assoc Phys India. 1994;42:690-1.

136. Thakur CP, Sinha GP, Pandey AK. Comparison of regimens of amphotericin B deoxycholate in kala-azar. Indian J Med Res. 1996;103:259-63.

137. Thakur CP, Kumar P, Kumar N, Singh GN, Singh AK, Narain S. A randomized comparison of classical mode of administration of amphotericin B with its newer modes of administration in kala-azar. J Assoc Phys India. 1998;46:779-83.

138. Thakur CP, Singh RK, Hassan SM, Kumar R, Narain S, Kumar A. Amphotericin B deoxycholate treatment of visceral leishmaniasis with newer modes of administration and precautions: a study of 938 cases. Trans R Soc Trop Med Hyg. 1999;93: 319-23. 